\title{
Cubic cobalt and zinc co-doped magnetite nanoparticles for persulfate and hydrogen peroxide activation towards the effective
} photodegradation of Sulfalene

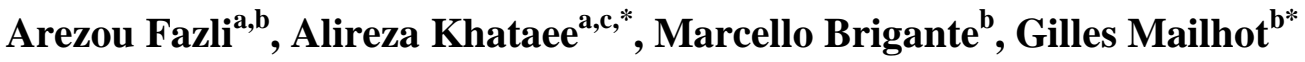 \\ ${ }^{a}$ Research Laboratory of Advanced Water and Wastewater Treatment Processes, Department of \\ Applied Chemistry, Faculty of Chemistry, University of Tabriz, 51666-16471, Tabriz, Iran \\ ${ }^{b}$ Université Clermont Auvergne, CNRS, SIGMA Clermont, Institut de Chimie de Clermont-Ferrand, \\ F-63000 Clermont-Ferrand, France \\ ${ }^{c}$ Institute of Research and Development, Duy Tan University, Da Nang 550000, Vietnam \\ * Corresponding authors: \\ a_khataee@tabrizu.ac.ir; alirezakhataee@duytan.edu.vn (A. Khataee) \\ gilles.mailhot@uca.fr (G. Mailhot)
}




\begin{abstract}
In this work, the cubic cobalt and zinc doped and co-doped magnetite nanocatalysts were synthesized and characterized using different analysis. The so-synthesized photocatalysts were used for the activation of hydrogen peroxide (HP) and persulfate (PS) under UVA irradiation. The integration of $\mathrm{Fe}_{2.5} \mathrm{Co}_{0.3} \mathrm{Zn}_{0.2} \mathrm{O}_{4}$ improved the activation of PS and HP; wherein, the $\mathrm{UVA} / \mathrm{Fe}_{2.5} \mathrm{Co}_{0.3} \mathrm{Zn}_{0.2} \mathrm{O}_{4} / \mathrm{PS}$ process demonstrated higher degradation performance for Sulfalene (SFL) as a veterinary pharmaceutical contaminant in water. Afterward, the effect of different physicochemical parameters was studied and the radicals generated through the process were identified using chemical scavengers. $\mathrm{UVA} / \mathrm{Fe}_{2.5} \mathrm{Co}_{0.3} \mathrm{Zn}_{0.2} \mathrm{O}_{4} / \mathrm{PS}$ process brought about $67 \%$ of $\mathrm{SFL}$ degradation in real wastewater. Moreover, $85 \%$ of TOC removal was achieved within $15 \mathrm{~h}$ of the abovementioned process. Eventually, the phototoxicity of the untreated and treated SFL solution after $120 \mathrm{~min}$ of the $\mathrm{UVA} / \mathrm{Fe}_{2.5} \mathrm{Co}_{0.3} \mathrm{Zn}_{0.2} \mathrm{O}_{4} / \mathrm{PS}$ process was studied using Lemna minor aquatic species.
\end{abstract}

Keywords: Photocatalysis; Magnetic catalysts; Persulfate activation; Hydroxyl radical; Sulfate radical; Wastewater; Mineralization. 


\section{Introduction}

Over the previous decades, the production and usage of pharmacologically active substances as animal medicines have raised due to the increased demand for animal production. Currently, various kinds of veterinary antibiotics (VAs) are being produced and consumed in the growing animal food industry to decrease the economic loss, assure the animal health, and promote the animal $[1,2]$. According to the literature review, the continuous release of the trace amount of VAs residues into the aquatic environment including groundwater and surface water provokes the antibiotic resistance in bacteria and consequently results in toxicity to plants, animals, and human beings [2]. Due to the water quality decrease and waterborne infections, creating productive strategies for the degradation of VAs has become an urgent issue and a hot topic among researchers [1,2]. Various kinds of techniques have been applied to the degradation of pharmaceutical compounds from water. However, the main challenge is to improve the treatment technologies to the new methods which are durable, less harmful, non-corrosive to equipment, cost-effective, and unconventional [3]. Recently, applied methods have been based on the well-known advanced oxidation processes (AOPs) coupling with the appropriate nanotechnology which offers different advantages such as (a) possessing an ability to apply under ambient temperature and pressure, (b) serving higher degradation rate, and (c) mineralizing of organic pollutants to the ubiquitous substances like $\mathrm{H}_{2} \mathrm{O}$, and $\mathrm{CO}_{2}$ [4]. Various kinds of AOPs such as photocatalysis [5,6], photoelectrocatalysis [7], Fenton [8], electro-Fenton [9], photo-Fenton [10] processes have been mainly regarded for degrading waterborne pharmaceutical pollutants by the expert scientists [11]. Besides the main advantages of the AOPs, some of them require specific design and considerable energy and inventory. However, the photocatalytic degradation process has witnessed rapid improvement which has been attributed to their effectiveness, simplicity, having no sludge, and being inexpensive [11]. This eco-friendly method is 
comprised of nano semiconductor photocatalysts which can produce photogenerated electronhole $\left(\mathrm{e}^{-} / \mathrm{h}^{+}\right)$pairs when they receive adequate photoenergy [12]. In the recent few years, the application of different metal oxides such as $\mathrm{ZrO}_{2}$ [13], $\mathrm{ZnO}$ [14], and $\mathrm{Fe}_{2} \mathrm{O}_{3}$ [15] as the proper nano-semiconductor photocatalysts have been progressed. Among the synthesized catalysts, magnetite nanocatalysts have proved to be excellent photocatalysts due to their decent photocatalytic properties, less toxicity, and higher separation or recovery efficiency which surmount the limitation of other photocatalysts and enable their use for industrial application [16]. In spite of the fact that the bulk magnetite exhibits many fascinating properties and it possesses a small bandgap, it still manifests low photocatalytic activity due to the high recombination of photo-induced $\mathrm{e}^{-} / \mathrm{holes}$. To deal with this issue, the researchers have done many attempts; (I) they have modified the tunable properties of magnetite by hybridizing with a speeding-up component and doping with different transition metals $[11,17]$, and (II) they integrated the photocatalysis with different oxidants as the electron acceptors for the decrement of $\mathrm{e}^{-} /$hole pair recombination [8]. According to the literature review, $\mathrm{Zn}$ and Co are the frequently used elements for doping in the materials $[18,19]$. Due to the remarkable redox properties of $\mathrm{Co}$ and $\mathrm{Zn}$, the existence of these elements in the structure of the magnetite brings about the oxygen vacancies and results in the capture of the photo-induced electrons which in turn can prevent the electron-hole recombination and increase the photocatalytic performance of the magnetite [18-21]. Moreover, it has been previously affirmed that the co-existence of transition metals in the structure of $\mathrm{Fe}_{3} \mathrm{O}_{4}$ can also result in an effective light-harvesting and proper separation of charge which consequently increase its photocatalytic performance [21]. On the other hand, it has been extensively reported that during the photocatalytic activity of the metal-promoted magnetite which depends on the redox cycling of $\mathrm{Fe}(\mathrm{III})$ and $\mathrm{Fe}(\mathrm{II})$, the low decomposition rate of some common oxidizers such as hydrogen HP and PS can be accelerated [22,23]. Hence, HP can be 
catalysed to generate mostly ${ }^{\circ} \mathrm{OH}$ radicals with oxidation potential of $2.7 \mathrm{eV}$ through heterogeneous photo-Fenton process [17] and PS with a similar structure to that of HP can be activated to form huge amounts of hydroxyl and sulfate radicals $\left(\mathrm{SO}_{4}{ }^{-{ }^{-}}\right)$with more oxidation potential $\left(\mathrm{E}_{0}=2.5-3.1 \mathrm{~V}\right)$ and higher half-life time $\left(\mathrm{t}_{1 / 2}, \mathrm{OH}=10^{-3} \mu\right.$ s and $\mathrm{t}_{1 / 2}, \mathrm{SO}_{4}{ }^{-{ }^{-}}=30-40$ $\mu$ ) [24]. $\mathrm{Zn}$ doped $\mathrm{Fe}_{3} \mathrm{O}_{4}$ [17] and Co substituted magnetite [25] were synthesized and their Photo-Fenton catalytic activity were studied. However, in the mentioned works the best reported catalytic activity is related to the lower $\mathrm{pH}$ and higher amounts of HP. Other scientists have utilized magnetic ferrospinel $\mathrm{MFe}_{2} \mathrm{O}_{4}$ with $\mathrm{M}=\mathrm{Co}, \mathrm{Cu}, \mathrm{Mn}$, and $\mathrm{Zn}$ to activate peroxymonosulfate; however, the photocatalytic activity of the as-synthesized catalysts were not studied [26]. To the best of our knowledge, the activation of PS and HP using the $\mathrm{Co}$ and $\mathrm{Zn}$ co-doped magnetite nanoparticles has not been studied and compared. Therefore, the novelty of this work lies on 1) the synthesis of new Co and $\mathrm{Zn}$ co-doped magnetite with high photocatalytic performance and 2) the integration of so-synthesized photocatalysts, oxidizing agent, and UVA for presenting a highly efficient system, as well as a $\mathrm{pH}$-independent process for the degradation of the newly emerged veterinary antibiotic. Thereafter, the optimum operational conditions as well as reusability of the catalysts were evaluated. After assessing the matrix impact of the real wastewater on the degradation efficiency of SFL under different processes, the high performance degradation process was applied for monitoring the fate of the SFL molecules in the contaminated water by assessing the TOC removal, and the toxicity of the produced intermediates during the treatment process.

\section{Material and methods}

\subsection{Chemicals}


Co (II) chloride hexahydrate $\left(\mathrm{CoCl}_{2} \cdot 6 \mathrm{H}_{2} \mathrm{O} 97 \%\right.$, Merck, Germany), Sodium nitrate $\left(\mathrm{NaNO}_{3} 99 \%\right.$, Merck, Germany), iron (II) chloride tetrahydrate, $\left(\mathrm{FeCl}_{2} \cdot 4 \mathrm{H}_{2} \mathrm{O} 99 \%\right.$, Merck, Germany), $\mathrm{Zn}$ (II) chloride tetrahydrate $\left(\mathrm{ZnCl}_{2} \cdot 4 \mathrm{H}_{2} \mathrm{O} 98 \%\right.$, Merck, Germany), hydrazine hydrate $\left(\mathrm{N}_{2} \mathrm{H}_{4} \cdot \mathrm{H}_{2} \mathrm{O} 90-100 \%\right.$, Rankem, India), hydrochloric acid ( $\mathrm{HCl} 38 \%$, Royalex) were used to synthesize cobalt and zinc doped magnetite. Sulfalene, 1,4-benzoquinone $\left(\mathrm{C}_{6} \mathrm{H}_{4} \mathrm{O}_{2}\right.$, $99 \%$ ), Potassium iodide (KI, 99.5\%), Sodium persulfate $\left(\mathrm{Na}_{2} \mathrm{~S}_{2} \mathrm{O}_{8}\right)$, sodium hydroxide ( $\mathrm{NaOH} 99 \%)$, Hydrogen peroxide $\left(\mathrm{H}_{2} \mathrm{O}_{2} 30 \%\right.$ solution), and organic solvents (purity > 99\%) were provided from Sigma Aldrich and used without any purification process. To investigate the wastewater matrix effect on the degradation efficiency of SFL, an effluent sample was collected in September 2019 after the primary treatment stages in a municipal wastewater treatment plant of the Metropole of Clermont-Ferrand, France.

\subsection{Synthesis of doped and co-doped magnetite nanocatalysts}

The previously published papers [12,21] were used for the synthesis of magnetite nanoparticles. In this context two different solutions were prepared separately as follows: for the solution (I) $100 \mathrm{~mL}$ of an alkaline solution of $0.908 \mathrm{M}$ of $\mathrm{NaNO}_{3}(7.718 \mathrm{~g})$ and $0.40 \mathrm{M}$ of $\mathrm{NaOH}$ (16.14 g) was prepared; thereafter, solution (II) was provided by dissolving $\mathrm{FeCl}_{2} \cdot 4 \mathrm{H}_{2} \mathrm{O}(0.9 \mathrm{M})$ in the deoxygenated mixture of $10 \mathrm{~mL}$ of $\mathrm{HCl}$ and milli-Q water and finally mixed with some drops of hydrazine. After that, the solution (I) was drop-wisely added to the solution (II) while it was heating up to $100{ }^{\circ} \mathrm{C}$ under mechanical stirring at a rate of $500 \mathrm{rpm}$. The addition of solution (I) occurred within $20 \mathrm{~min}$ and then the reaction was maintained at $95{ }^{\circ} \mathrm{C}$ and continued stirring under $\mathrm{N}_{2}$ gas for $2 \mathrm{~h}$. The obtained solution was cooled down to room temperature, and a magnet was used to collect the synthesized nanoparticles. Afterward, the particles were washed 3 times with the boiling deionized water and ethanol. Finally, the particles were collected and subsequently dried in an oven for $24 \mathrm{~h}$ 
at $90-100{ }^{\circ} \mathrm{C}$. The same procedure was carried out to prepare doped or co-doped magnetite; however, in these cases solution (II) consists of $\mathrm{FeCl}_{2} \cdot 4 \mathrm{H}_{2} \mathrm{O}$ in the presence of $\mathrm{CoCl}_{2} \cdot 6 \mathrm{H}_{2} \mathrm{O}$, $\mathrm{ZnCl}_{2} \cdot 4 \mathrm{H}_{2} \mathrm{O}$, and both of them for $\mathrm{Co}, \mathrm{Zn}$, and Co- $\mathrm{Zn}$ co-doped magnetite, respectively.

The yield percentage of doped and co-doped magnetite nanoparticles was calculated using the equation $\frac{\mathrm{W}_{\mathrm{p}}}{\mathrm{W}_{\mathrm{t}}} \times 100$ where $\mathrm{W}_{\mathrm{p}}$ is the total weight of gained doped or co-doped magnetite, and $\mathrm{W}_{\mathrm{t}}$ is the total weight of the used $\mathrm{FeCl}_{2} \cdot 4 \mathrm{H}_{2} \mathrm{O}, \mathrm{ZnCl}_{2} \cdot 4 \mathrm{H}_{2} \mathrm{O}$, and $\mathrm{CoCl}_{2} \cdot 6 \mathrm{H}_{2} \mathrm{O}$ in the course of the synthesis. Accordingly, the nanoparticle yield percentage of the $\mathrm{Co}$ and $\mathrm{Zn}$ doped and co-doped magnetite was found to be in the range of $89 \%-93 \%$.

\subsection{Catalysts characterization}

Different characterizations were accomplished to identify the synthesized doped and codoped magnetite nanoparticles. X-ray diffraction (XRD, D8 Advance, Bruker, Germany) analysis was utilized to determine the crystalline phase (applying $\mathrm{Cu}-\mathrm{K} \alpha$ radiation at 0.15406 $\mathrm{nm}$ at accelerating voltage and current of $45 \mathrm{kV}, 40 \mathrm{~mA}$ ). The surface morphologies were studied by applying transmission electron microscopy (TEM, JEM-2200FS, JEOL, Japan). The energy-dispersive X-ray (EDX), scanning electron microscopy (SEM), as well as X-ray dot-mapping analysis, were studied by using a Tescan Mira3 microscope (Czech Republic). In order to study the functional groups of the nanoparticles, FTIR spectra were recorded by employing a Tensor 27, Bruker (Germany) spectrophotometer in the wavelength range of 400-4000 $\mathrm{cm}^{-1}$ using the $\mathrm{KBr}$ disk method. Compositional analysis was performed by adopting X-ray photoelectron spectroscopy (XPS) analysis was accomplished in a UHV chamber (pressure $10^{-7} \mathrm{~Pa}$ ) facilitated with an XPS system (hemispherical electron energy analyzer OMICRON EA125, Germany). The optical bandgap of the as-synthesized nano photocatalysts was assigned using the absorbance data of Diffuse Reflectance 
Spectrophotometer (DRS, S 250, Germany). A typical vibrating sample magnetometer (VSM, Lakeshore, 7400 Series) was used to evaluate the magnetic behavior of samples. The pore volume and the specific surface area were tried to be investigated by Brunauer Emmett Teller (BET) method utilizing a 3 Flex instrument (Micromeritics, USA) via $\mathrm{N}_{2}$ adsorption/desorption isotherms at $77 \mathrm{~K}$. Leaching concentrations of iron, cobalt, and zinc were quantified by an inductively coupled plasma emission spectroscopy (ICP-AES) using a Jobin-Yvon ULTIMA C instrument (USA).

The point of zero charges $\left(\mathrm{pH}_{\mathrm{pzc}}\right)$ of the synthesized catalysts was determined according to the salt addition method [27]. Hence, $500 \mathrm{~mL} 0.01 \mathrm{M} \mathrm{NaCl}$ solution was divided into eight similar Erlenmeyer flasks; afterward, $\mathrm{NaOH}(0.1 \mathrm{M})$ and $\mathrm{HCl}(0.1 \mathrm{M})$ solutions were used to adjust the pHs of the solutions. Then, $0.2 \mathrm{~g}$ of the so-synthesized nanoparticles were added to each flask. A shaker (Julabo SW22, Germany) was set at $150 \mathrm{rpm}$ to shake the suspensions at $25{ }^{\circ} \mathrm{C}$ for $48 \mathrm{~h}$.

\subsection{Photocatalytic degradation experiments}

Photocatalytic experiments were performed in a Pyrex jacked cylindrical reactor surrounded by four Philips TLD 15W tubular lamps placed in the four axes with emission from 300 to $420 \mathrm{~nm}$ (with a maximum at $365 \mathrm{~nm}$ ). The information about the emission spectrum of lamps reaching the solution as well as the adopted measurement method was reported in the Supporting Information. Solutions were stirred during irradiation and temperature was kept constant at $20{ }^{\circ} \mathrm{C}$ through a water circulation system connected to a water cooling system. In a typical experiment, a desired quantity of the catalyst was added to a $100 \mathrm{~mL}$ solution of SFL $(25 \mu \mathrm{M})$ with the predetermined amounts of HP or PS. Then, the solution was irradiated and $5 \mathrm{~mL}$ of samples were withdrawn at the determined reaction time intervals wherein the solid catalysts were removed by using syringe filters $0.2 \mu \mathrm{m}$ 
(Macherey-Nagel, Germany). In order to ensure that the reaction was stopped, $1 \mathrm{~mL}$ of methanol was added to the filtered solution and subsequently analyzed using an Ultra Performance Liquid Chromatography (Alliance, Waters, USA) equipped with a photodiode array detector (Waters, USA). The eluent was a mixture of phosphate buffer $(0.1 \mathrm{M})$ and methanol and $(55 / 45, \mathrm{v} / \mathrm{v})$ with the isocratic mode at a flow rate of $0.2 \mathrm{~mL} \mathrm{~min}^{-1}$. The used column was Acquity UPLC BEH C18 of $2.1 \times 100 \mathrm{~mm}$ with a particle size of $1.7 \mu \mathrm{m}$. It is worthy to note that the SFL retention time was $3.5 \mathrm{~min}$. Finally, the degradation efficiency

(DE) was determined using the equation $\frac{C_{0}-C_{t}}{C_{0}} \times 100$ where $\mathrm{C}_{0}$ and $\mathrm{C}_{\mathrm{t}}$ are the initial and the residual concentration of SFL $(\mathrm{mM})$ at time $\mathrm{t}$, respectively.

In order to determine the possible adsorption of SFL on the catalysts, the same experiments were fulfilled for each catalyst in dark condition and absence of oxidants. For the reusability tests, the utilized catalyst in the first run was collected and reused for the other 4 runs. $\mathrm{HClO}_{4}$ and $\mathrm{NaOH}$ were used to adjust the $\mathrm{pH}$ of the solution to the desired value.

TOC of the SFL solution was determined before and at different reaction times using a TOC analyzer (Shimadzu, TOC-L, Japan). The solutions were irradiated for $60 \mathrm{~h}$ and $7 \mathrm{~mL}$ of the samples were withdrawn at fixed time intervals $(1,2,5,10,15,30$, and $60 \mathrm{~h})$ and analyzed to determine the TOC removal efficiency.

\subsection{Ecotoxicological investigation of the process}

Fronds of duckweed (Lemna minor) were collected from the Anzali Wetland in the North of Iran. After disinfecting and washing with $0.5 \% \mathrm{v} / \mathrm{v}$ sodium-hypochlorite and distilled water, they were cultivated by the culture medium as described in the literature [28]. Then, the SFL solution was treated by applying the degradation process in the presence of Co-Zn co-doped magnetite under the obtained optimal condition. $10 \mathrm{~mL}$ of SFL solutions were 
withdrawn from the reactor at $0,60,120,240 \mathrm{~min}$. Consequently, $10 \mathrm{~mL}$ of nutrient medium was added to the mentioned solutions and the conversions in the frond color and colony integrity were compared with the control solution containing $10 \mathrm{~mL}$ of nutrient medium. In order to observe the alteration of the fronds, the stereomicroscope (Olympus, Japan) was employed.

\section{Results and discussion}

\subsection{Characterization of synthesized nanocatalysts}

According to the literature review [29], during the co-precipitation method, the synthesis of magnetite nanoparticles takes place after three main steps comprising of nucleation, growth of precipitate, and finally completion of magnetic nanoparticles phases [29]. At the nucleation stage, the hydroxyl anions of the basic solution react with the available $\mathrm{Fe}^{2+}$ in the solution [30]. This step was represented by the direct change of solution color from green to black due to the generation of the magnetic nanoparticles nuclei. On the other hand, it has been previously affirmed that the presence of $\mathrm{NaNO}_{3}$ influences the crystallite formation, owing to its ability to raise the ionic strength in the reaction media which in turn slows down the growth of magnetite particles and lowers its crystal size [30,31]. Therefore, it is expected that the presence of $\mathrm{NaNO}_{3}$ results in the slower growth of the formed nuclei in the first stage and finally brings about the preparation of magnetite nanoparticles with low crystal size [31]. Moreover, it has been proved that the crystal growth resulted from element doping ascribes to the initial nucleation stage and/or growth process [30]. Therefore, many scientists have added the solution of doping metal ions to the prepared acidic solution of $\mathrm{FeCl}_{2} \cdot 4 \mathrm{H}_{2} \mathrm{O}$ in the first step and before the nucleation stage to bring about the incorporation of the metal ions to the lattice of the magnetite and avoid the formation of the metal hydroxide as the side product. Therefore, in the present work, $\mathrm{Zn}$ or Co doped, and co-doped magnetite nanoparticles were 
synthesized using the previously described co-precipitation method, and their successful synthesis, as well as the morphology, crystal size, and other properties, were evaluated by different analysis as follows.

SEM and TEM images were performed in order to evaluate the structural morphology of prepared nanocatalysts along with their size determinations. Fig. 1 displays the SEM, TEM, and size distribution spectra of the pure magnetite and co-doped magnetite. By studying those micrographs, it is clear that the cubic structured morphology and uniform nanoparticles were obtained with an average size of about 79.9 and $23.0 \mathrm{~nm}$ for pure $\mathrm{Fe}_{3} \mathrm{O}_{4}$ and $\mathrm{Fe}_{2.5} \mathrm{Co}_{0.3} \mathrm{Zn}_{0.2} \mathrm{O}_{4}$, respectively. Moreover, the uniform cubic nanoparticles with the mean size of 56.038 and $51.018 \mathrm{~nm}$ were observed for $\mathrm{Fe}_{2.7} \mathrm{Zn}_{0.3} \mathrm{O}_{4}$ and $\mathrm{Fe}_{2.7} \mathrm{Co}_{0.3} \mathrm{O}_{4}$, respectively (Supplementary Fig. S1). The growth mechanism and the effect of Co and Zn doping on the crystal size of magnetite synthesized via precipitation method has been reported before $[17,32]$. Comparing the obtained results, the magnetic structure was preserved after doping or co-doping elements; however, the grain size of the samples declined in the order of $\mathrm{Fe}_{3} \mathrm{O}_{4}>$ $\mathrm{Fe}_{2.7} \mathrm{Zn}_{0.3} \mathrm{O}_{4}>\mathrm{Fe}_{2.7} \mathrm{Co}_{0.3} \mathrm{O}_{4}>\mathrm{Fe}_{2.5} \mathrm{Co}_{0.3} \mathrm{Zn}_{0.2} \mathrm{O}_{4}$ which accords with the results obtained for the doped and co-doped magnetite nanoparticles [21,33]. Moreover, these acquired results are in good agreement with the data obtained from BET analysis. 


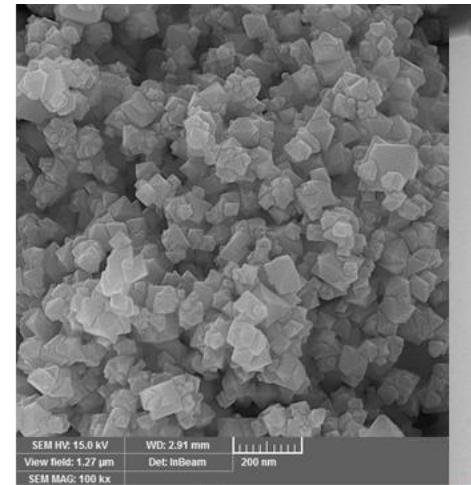

(a)

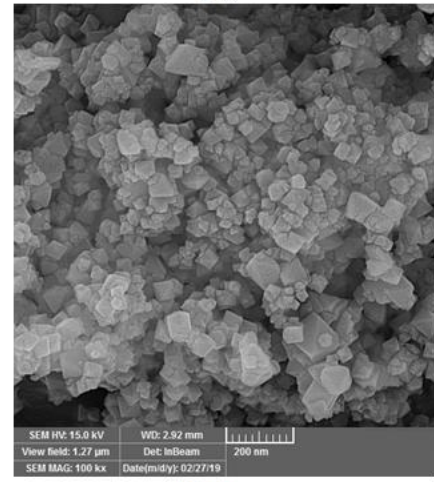

(d)

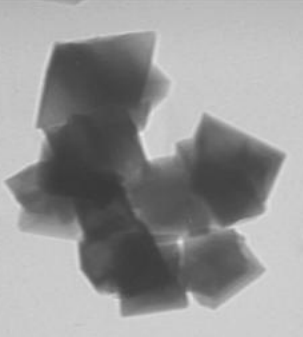

(b)

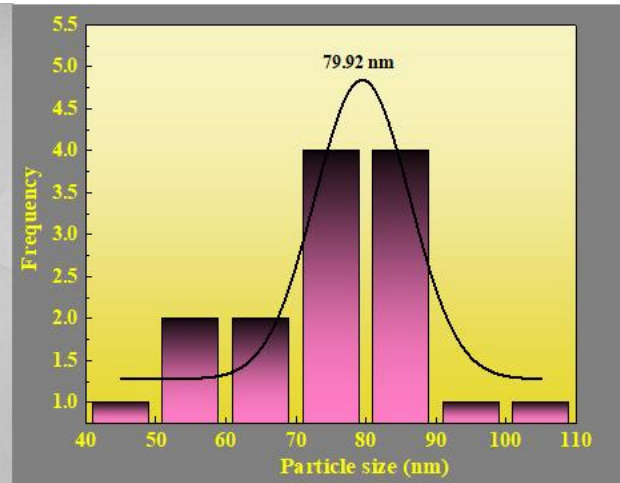

(c) $\overline{50 \mathrm{~nm}}$

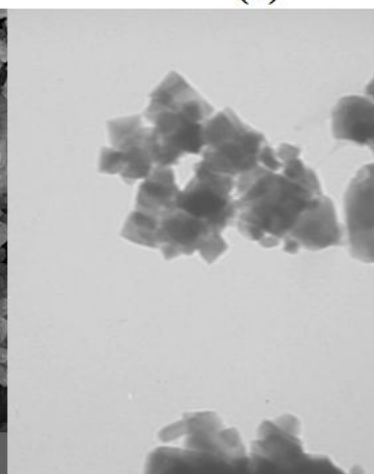

(e)

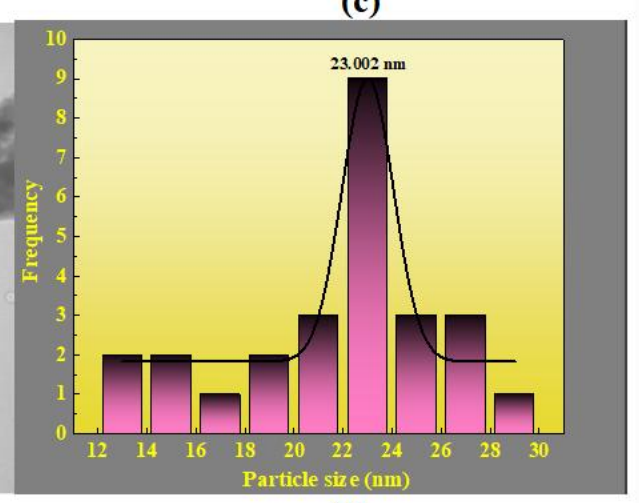

(f)

Fig. 1. SEM, TEM, and size distribution spectrum of (a, b, and c) the pure magnetite $\left(\mathrm{Fe}_{3} \mathrm{O}_{4}\right)$ and (d, e, and f) co-doped magnetite $\left(\mathrm{Fe}_{2.5} \mathrm{Co}_{0.3} \mathrm{Zn}_{0.2} \mathrm{O}_{4}\right)$.

Energy-dispersive X-ray (EDX) spectra accompanied by the relative weight \% and atomic $\%$ of elements were studied to assess the elemental composition of the so-synthesized samples (Supplementary Fig. S2). The obtained data was a piece of good evidence for the existence of $\mathrm{Zn}, \mathrm{Co}$, and both of them in the as-synthesized doped or co-doped nanocatalysts.

Afterward, a Dot-mapping analysis was undertaken to survey the elemental distribution in $\mathrm{Fe}_{2.5} \mathrm{Co}_{0.3} \mathrm{Zn}_{0.2} \mathrm{O}_{4}$ (Supplementary Fig. S3). The color of distribution patterns for Fe, Co, $\mathrm{Zn}$ were respectively selected to be yellow, blue, and pink. The incorporated elements exhibit a homogeneous distribution in the structure of the co-doped magnetite.

Furthermore, the structure of the as-prepared pure, doped, and co-doped magnetite was verified using XRD patterns (Fig. 2a). The patterns illustrate the diffraction peaks ascribed to magnetite at $2 \theta$ angle of $18.3^{\circ}, 30.01^{\circ}, 35.5^{\circ}, 36.5^{\circ}, 43.3^{\circ}, 53.9^{\circ}, 57.8^{\circ}, 62.9^{\circ}$, and $74.3^{\circ}$ which 
are corresponded to (111), (220), (311), (222), (400), (422), (511), (440), and (533) crystal planes of cubic spinel structure of $\mathrm{Fe}_{3} \mathrm{O}_{4}$ (JCPDS no. 01-089-0951). According to Fig. 2a, the diffracted peaks of the doped and co-doped magnetite samples are similar but with a reduced intensity along with the shift of the peaks to the higher $2 \theta$ degrees. The similar diffraction peaks of all the samples verified that the doping did not affect the appearance of the impurity peaks. Taking account of the growth mechanism presented for the doped magnetite [30], the doping metal ions have been incorporated into the lattice of the magnetite maintaining the phase purity with the cubic spinel structure of all the samples. On the other hand, the shift of the diffracted peak positions to the higher $2 \theta$ degrees in the doped and co-doped magnetite revealed the substitution of the $\mathrm{Fe}^{2+}$ (ion radius $=78 \mathrm{pm}$ ) with $\mathrm{Co}^{2+}$ and $\mathrm{Zn}^{2+}$ (ion radius = 74.5, and $74 \mathrm{pm}$, respectively). Furthermore, the intensity of the peaks in the doped and codoped samples was only rather reduced as compared with pure magnetite. This reduction can be interpreted as the reduced crystalline nature of the samples and the decline in the particle size of doped and co-doped magnetite samples [34]. In this context, the Scherrer formula was applied to calculate the mean grain size of the samples by using the acquired data from the XRD pattern such as FWHM and $\theta$ in radian [34]. The obtained mean particle size which correlates well with the achieved results from BET and TEM analysis (Table 1). 

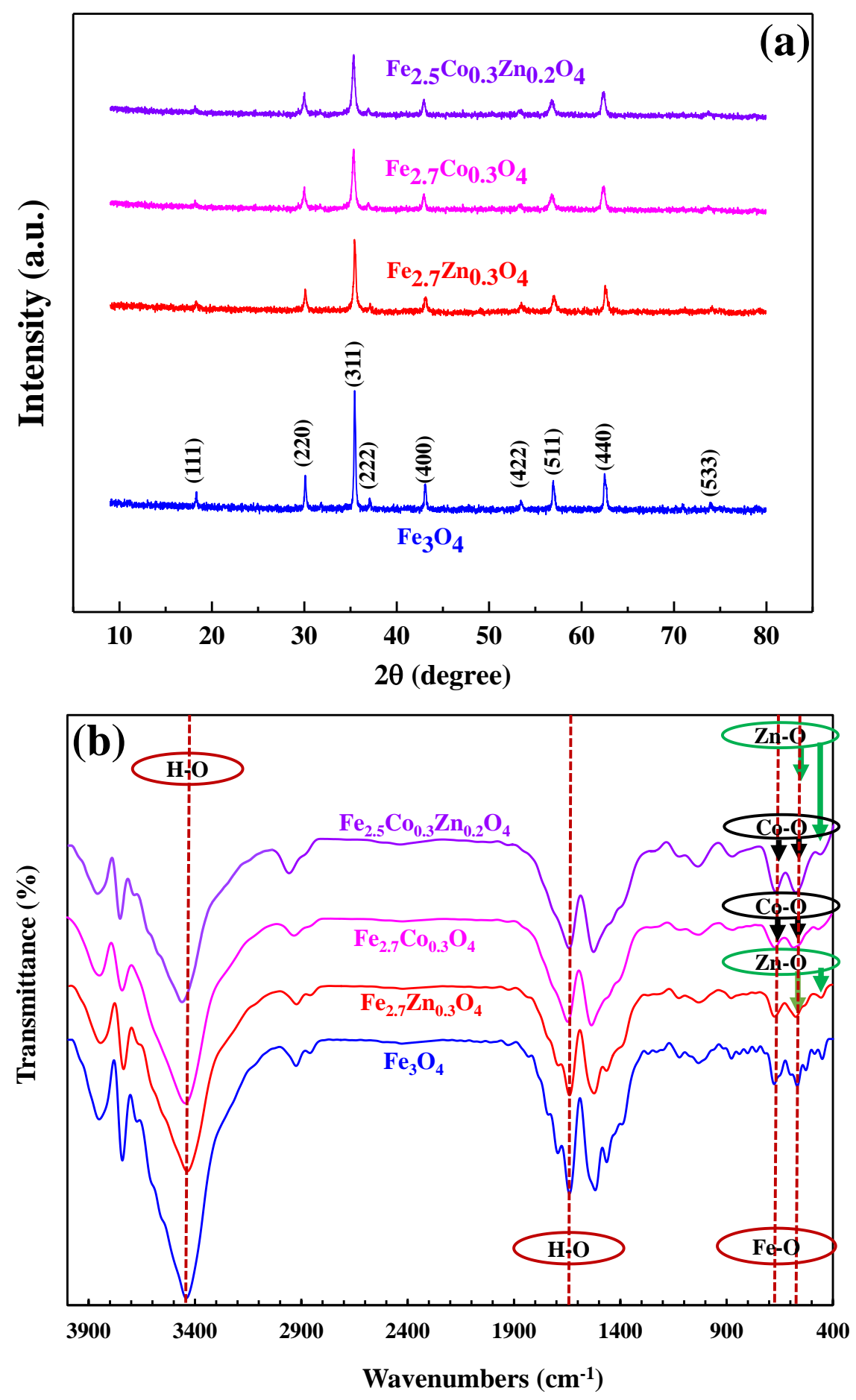

Fig. 2. (a) XRD and (b) FTIR, spectra of the synthesized nanocatalysts.

Any variation of the specific surface area and pore volume for pure and doped magnetite were investigated by carrying out the BET analysis. Accordingly, the $\mathrm{N}_{2}$ adsorption- 
desorption isotherms are demonstrated in Fig. S4 and the related values were tabulated in Table 1.

Table 1. The Brunauer-Emmett-Teller surface areas, pore-volume, pore sizes obtained from the BET analysis, as well as, the mean particle size of the so-synthesized samples attained from the XRD results.

\begin{tabular}{lcccc}
\hline Samples & $\mathbf{S}_{\mathbf{B E T}}\left(\mathbf{m}^{2} \mathbf{g}^{-1}\right)$ & $\mathbf{V}_{\mathbf{P}}\left(\mathbf{c m}^{3} \mathbf{g}^{-1}\right)$ & $\mathbf{d}_{\mathbf{p}}(\mathbf{n m})$ & Mean particle size (nm) \\
\hline $\mathrm{Fe}_{3} \mathrm{O}_{4}$ & 8.12 & 0.342 & 48.54 & 70.12 \\
\hline $\mathrm{Fe}_{2.7} \mathrm{Zn}_{0.3} \mathrm{O}_{4}$ & 14.37 & 0.323 & 36.92 & 52.01 \\
\hline $\mathrm{Fe}_{2.7} \mathrm{Co}_{0.3} \mathrm{O}_{4}$ & 18.34 & 0.321 & 30.12 & 47.21 \\
\hline $\mathrm{Fe}_{2.5} \mathrm{Co}_{0.3} \mathrm{Zn}_{0.2} \mathrm{O}_{4}$ & 25.18 & 0.311 & 20.91 & 21.65 \\
\hline
\end{tabular}

The surface area of the samples increased with co-doping of Co and $\mathrm{Zn}$ in the structure of the magnetite due to the reduced mean particle size in the $\mathrm{Fe}_{2.5} \mathrm{Co}_{0.3} \mathrm{Zn}_{0.2} \mathrm{O}_{4}$. Considering the IUPAC classification, the figures related to the nitrogen gas adsorption/desorption of the prepared samples can be classified as type- III. It has been denoted that the adsorbents with the pore diameters ranged between $2-50 \mathrm{~nm}$ are mesoporous [35]. The average pore diameter for our so-synthesized samples is varied between 20 and $50 \mathrm{~nm}$ which reveals the presence of mesopores in the prepared nanomaterials. Moreover, doping $\mathrm{Zn}$ and Co to the structure of the pure $\mathrm{Fe}_{3} \mathrm{O}_{4}$ enhanced the surface area from $8.12 \mathrm{~m}^{2} \mathrm{~g}^{-1}$ to 14.37 , and $18.34 \mathrm{~m}^{2} \mathrm{~g}^{-1}$ respectively. Whereas, co-doping of $\mathrm{Co}$ and $\mathrm{Zn}$ to the magnetite varied up the surface area to $25.18 \mathrm{~m}^{2} \mathrm{~g}^{-1}$. The enhanced specific surface area is in accordance with the smaller grain size of the $\mathrm{Fe}_{2.5} \mathrm{Co}_{0.3} \mathrm{Zn}_{0.2} \mathrm{O}_{4}$ in comparison with the other samples.

Fig. $2 b$ shows the FTIR spectrums of the prepared samples to seek the functional groups and their variation by adding any impurities inside the structure of the pristine magnetite. The 
absorption peaks at $1620 \mathrm{~cm}^{-1}$ and $3410 \mathrm{~cm}^{-1}$ ascribes to the $\mathrm{H}-\mathrm{O}-\mathrm{H}$ bending and stretching vibration of the adsorbed or free water, respectively [36]. Additionally, the absorption bands at 570 and $680 \mathrm{~cm}^{-1}$ were associated with the presence of $\mathrm{Fe}-\mathrm{O}$ stretching vibration in all the samples which mostly declares the maintenance of the magnetite structure in the doped or codoped samples. Nonetheless, the enhanced intensities of the peaks along with the small shift in the peak position correspondent to the $\mathrm{Fe}-\mathrm{O}$ stretching vibration acknowledge the proper incorporation of $\mathrm{Zn}$, Co within $\mathrm{Fe}_{3} \mathrm{O}_{4}$ structure.

The catalyst recovery to treat water is of great importance due to the economic point of view [37]. Therefore, the VSM measurement was carried out to study the magnetic properties of the pure magnetite and its variation after doping or co-doping of Co, and $\mathrm{Zn}$. By studying the hysteresis loops which are shown in Fig. S5, the specific magnetic parameters such as magnetic saturation $\left(\mathrm{M}_{\mathrm{s}}\right)$ and coercivity $\left(\mathrm{H}_{\mathrm{c}}\right)$ were extracted and documented in Table 2. According to the literature [38], a slim hysteresis loop with low residual magnetization $\left(\mathrm{M}_{\mathrm{r}}\right)$ and residual magnetization and the high magnetic saturation $\left(\mathrm{M}_{\mathrm{s}}\right)$ is the characteristic of the ferromagnetic materials. The achieved results show appropriate magnetic properties for pure $\mathrm{Fe}_{3} \mathrm{O}_{4}$ with $74 \mathrm{emu} \mathrm{g}{ }^{-1}$ of saturation magnetization. On the other hand, doping and co-doping of the magnetite with $\mathrm{Co}$, and $\mathrm{Zn}$ resulted in $\mathrm{Ms}$ of 69,66 , and $63 \mathrm{emu} \mathrm{g}^{-1}$ respectively, which still affirms the presence of a satisfying magnetic property and consequently a simple recovery of the samples from the treated water.

Table 2. The magnetic characterization of prepared samples.

\begin{tabular}{lccc}
\hline Samples & $\mathbf{H}_{\mathbf{c}}(\mathbf{G})$ & $\mathbf{M}_{\mathbf{s}}\left(\mathbf{e m u ~}^{-1}\right)$ & $\mathbf{S Q R}\left(\mathbf{M}_{\mathbf{r}} / \mathbf{M}_{\mathbf{s}}\right)$ \\
\hline $\mathrm{Fe}_{3} \mathrm{O}_{4}$ & 188 & 74 & 0.162 \\
\hline $\mathrm{Fe}_{2.7} \mathrm{Zn}_{0.3} \mathrm{O}_{4}$ & 190 & 69 & 0.165 \\
\hline $\mathrm{Fe}_{2.7} \mathrm{Co}_{0.3} \mathrm{O}_{4}$ & 193 & 66 & 0.166 \\
\hline
\end{tabular}




$\begin{array}{llll}\mathrm{Fe}_{2.5} \mathrm{Co}_{0.3} \mathrm{Zn}_{0.2} \mathrm{O}_{4} & 200 & 63 & 0.168\end{array}$

The XPS results were applied to investigate the surface elemental states and the elemental compositions for $\mathrm{Fe}_{2.5} \mathrm{Co}_{0.3} \mathrm{Zn}_{0.2} \mathrm{O}_{4}$. The results presented in Fig. S6 (a) accords with EDX results and prove the existence of $\mathrm{Fe}, \mathrm{Co}, \mathrm{Zn}, \mathrm{O}$ in the $\mathrm{Fe}_{2.5} \mathrm{Co}_{0.3} \mathrm{Zn}_{0.2} \mathrm{O}_{4}$ sample. The peak related to the presence of $\mathrm{C}$ in the samples was shown in the survey peak which can be related to the existence of impurities. Moreover, Fig. S6 (b) to (e) represent the gained narrow scans for Fe 2p, Co2p, Zn 2p, and O1s which were delineated in the range with the binding energy (BE) of 717-740, 772-795, 1010-1050, and 528-536 eV, respectively. According to the literature [17], four resolved sub-peaks from the related $\mathrm{Fe} 2 \mathrm{p}_{3 / 2}$ peak imply the presence of $\mathrm{Fe}^{2+}$ and $\mathrm{Fe}^{3+}$ on the surface of the sample. Furthermore, the peaks at BE of 781 and 793 ascribed to Co $2 \mathrm{p}_{3 / 2}$ and $\operatorname{Co} 2 \mathrm{p}_{1 / 2}$, respectively. Moreover, the presence of a satellite peak at 787.8 illustrates the existence of $\mathrm{Co}_{3} \mathrm{O}_{4}$ [39]. As it clear from Fig. S6 (d), the peaks at 1045.2, and $1020.8 \mathrm{eV}$ correspond to $\mathrm{Zn} 2 \mathrm{p}_{1 / 2}$ and $\mathrm{Zn} 2 \mathrm{p}_{3 / 2}$, respectively. This result can be a prominent sign of the presence of $\mathrm{Zn}^{2+}$ on the surface of the co-doped magnetite [40]. Moreover, considering the results presented in the literature, the related sub-peaks for $\mathrm{O} 1 \mathrm{~s}$ peak can be attributed to $\mathrm{O}$ atoms in the hydroxyl groups and absorbed water, and finally the presence of the metal-oxygen bonds [39].

UV-Vis DRS analysis was applied for studying the impact of metal-doping on the optical absorption of magnetite. Fig. S7 depicts the plot of (Ahv) ${ }^{2}$ vs. (hv) [41] for pure, doped, and co-doped magnetite. The linear region of the plots was extrapolated to record the bandgap of the samples. The results demonstrated the ban gaps of 3.25, 3.1, 2.88, $2.69 \mathrm{eV}$ for pure $\mathrm{Fe}_{3} \mathrm{O}_{4}$, $\mathrm{Fe}_{2.7} \mathrm{Zn}_{0.3} \mathrm{O}_{4}, \mathrm{Fe}_{2.7} \mathrm{Co}_{0.3} \mathrm{O}_{4}$, and $\mathrm{Fe}_{2.5} \mathrm{Co}_{0.3} \mathrm{Zn}_{0.2} \mathrm{O}_{4}$, respectively. It is clear that metal-doping can provide a decreasing effect on the bandgap of the semiconductors. However, co-doping of $\mathrm{Co}$ and $\mathrm{Zn}$ to the structure of the magnetite resulted in lower bandgap comparing with the 
sole doping of $\mathrm{Zn}$ and $\mathrm{Co}$. Therefore, $\mathrm{Fe}_{2.5} \mathrm{Co}_{0.3} \mathrm{Zn}_{0.2} \mathrm{O}_{4}$ can absorb a higher amount of light in the UV-vis region which can result in an improvement in charge separation, and consequently promoted photocatalytic performance.

\subsection{SFL degradation using different magnetic nanoparticles}

In the present work, before the evaluation of SFL degradation performance under different degradation processes, the adsorption equilibrium of SFL on the surface of the catalyst was assessed. Accordingly, the solution was stirred for $2 \mathrm{~h}$ in the dark condition and at the solution $\mathrm{pH}$ of 8 . The attained results revealed that the SFL molecules were adsorbed on the surface of the catalysts and almost equilibrated after $30 \mathrm{~min}$. Consequently, less than $8 \%$ of SFL was achieved to be absorbed on each of the magnetite nanoparticles (these results have not been presented). It was found out that the adsorption efficiency of the prepared samples was low; however, SFL adsorption was slightly enhanced by applying Co and $\mathrm{Zn}$ co-doped magnetite owing to its higher surface area. Therefore, before each experiment, the solution was stirred for $30 \mathrm{~min}$ under dark to gain the adsorption equilibrate and take a sample. Afterward, oxidant-assisted photocatalytic degradation was started and investigated. As reported in Fig. S8, the results verified that the photocatalytic degradation efficiency of SFL was slight for the pure and $\mathrm{Zn}$ doped magnetite. However, the photocatalytic activity was increased for Co doped and $\mathrm{Zn} / \mathrm{Co}$ co-doped magnetite, arousing from the reduction in their bandgap energy. The obtained results accord with the findings of the previously published papers in which the photocatalytic performance of magnetite nanoparticles has increased due to the positive effect of the doped metals in suppressing the recombination of photogenerated $\mathrm{e}^{-} /$holes $[40]$.

On the other hand, the activation of PS and HP by sole UVA gave the DE of $19 \%$ and 5\%, implying the lower decomposition rate of the oxidants. Regarding Fig. S8 (a), the 
PS/catalyst/UVA process tended to have higher removal efficiency. The same results have been gained in another research [42] in which the photocatalytic degradation of Orange II was evaluated by the assistance of $\mathrm{ZnFe}_{2} \mathrm{O}_{4}$ and persulfate. The improved DE can be aroused from the produced active radicals during the reaction. Considering Eqs. 1 to $7[43,44]$ the improved performance of the process can be related to some factors: a) the irradiated bandgap of the photocatalysts generate electron-hole which participate in the generation of hydroxyl radical $\left({ }^{\circ} \mathrm{OH}\right)$ or directly oxidize SFL, b) PS react with photogenerated $\mathrm{e}^{-}$, c) PS can react with $\mathrm{M}^{\mathrm{n}+}\left(\mathrm{Fe}^{2+}, \mathrm{Co}^{2+}, \mathrm{Zn}^{2+}\right)$ on the catalyst surface and yield their redox pairs $\mathrm{M}^{\mathrm{n}+1}\left(\mathrm{Fe}^{3+}\right.$, $\mathrm{Co}^{3+}, \mathrm{Zn}^{3+}$ ) as well as sulfate radicals [24], d) ${ }^{\circ} \mathrm{OH}$ as well can be produced via Eq. (6), and e) the utilized $\mathrm{M}^{\mathrm{n}+}$ species can finally be regenerated.

Photocatalyst $+\mathrm{hv} \rightarrow$ Photocatalyst $\left(\mathrm{h}^{+}+\mathrm{e}^{-}\right)$

$\mathrm{h}^{+}+\mathrm{H}_{2} \mathrm{O} \rightarrow \mathrm{H}^{+}+{ }^{\cdot} \mathrm{OH}$

$\mathrm{h}^{+}+\mathrm{OH}^{-} \rightarrow{ }^{\circ} \mathrm{OH}$

$\mathrm{S}_{2} \mathrm{O}_{8}{ }^{2-}+\mathrm{e}^{-} \rightarrow \mathrm{SO}_{4}{ }^{--}+\mathrm{SO}_{4}{ }^{2-}$

$\equiv \mathrm{M}^{\mathrm{n}+}+\mathrm{S}_{2} \mathrm{O}_{8}{ }^{2-} \rightarrow \equiv \mathrm{M}^{\mathrm{n}+1}+\mathrm{SO}_{4}{ }^{--}+\mathrm{SO}_{4}{ }^{2-}$

$\mathrm{SO}_{4}{ }^{--}+\mathrm{H}_{2} \mathrm{O} \rightarrow \mathrm{H}^{+}+{ }^{\circ} \mathrm{OH}+\mathrm{SO}_{4}{ }^{2-}$

$\equiv \mathrm{M}^{\mathrm{n}+1}+\mathrm{e}^{-} \rightarrow \equiv \mathrm{M}^{\mathrm{n}+}$

Moreover, the same procedure was applied and evaluated for assessing the DE in the presence of HP. As like as the results obtained for UV/catalyst/PS, the UV/catalyst/HP process enhanced the DE of SFL after 120 min of reaction time. The effective performance of this process can be attributed to the occurrence of Eqs. 1,2, 3, 7 and the further equation as follows [45].

$\equiv \mathrm{M}^{\mathrm{n}+}+\mathrm{H}_{2} \mathrm{O}_{2} \rightarrow \equiv \mathrm{M}^{\mathrm{n}+1}+{ }^{\cdot} \mathrm{OH}+{ }^{-} \mathrm{OH}$

Given the results obtained from this section, after $120 \mathrm{~min}$ of irradiation, the removal efficiency increased as the order of $\mathrm{Fe}_{2.5} \mathrm{Co}_{0.3} \mathrm{Zn}_{0.2} \mathrm{O}_{4}>\mathrm{Fe}_{2.7} \mathrm{Co}_{0.3} \mathrm{O}_{4}>\mathrm{Fe}_{2.7} \mathrm{Zn}_{0.3} \mathrm{O}_{4}>\mathrm{Fe}_{3} \mathrm{O}_{4}$; 
wherein, the DE was obtained to be $57 \%$ and $23 \%$ in the presence of co-doped magnetite, PS or HP, respectively. The uppermost photocatalytic performance of co-doped magnetite can be related to its appropriate performance in light responding, high charge separation capability, and appropriate participation of the doped elements in the activation of the oxidants [24].

As the UVA/Fe ${ }_{2.5} \mathrm{Co}_{0.3} \mathrm{Zn}_{0.2} \mathrm{O}_{4} / \mathrm{PS}$ process showed high performance in the degradation of SFL, the effect of integrating the co-doped magnetites, UVA, and PS was studied in detail. Fig. 3a demonstrates the results of studying the pseudo-first-order decay of SFL $\left(\mathrm{k}_{\mathrm{app}}, \mathrm{min}^{-1}\right)$ in the presence of different processes such as adsorption, photocatalytic degradation, UVlight activated persulfate, and finally photocatalytic activation of the PS. Taking consideration of the obtained results, all the studied processes showed the correlation coefficient $\left(\mathrm{R}^{2}\right)$ values more than 0.9 , indicating that all the systems followed pseudo-firstorder kinetics which accords with the literature [21,46]. Considering Fig. 3a, the $\mathrm{UVA} / \mathrm{Fe}_{2.5} \mathrm{Co}_{0.3} \mathrm{Zn}_{0.2} \mathrm{O}_{4} / \mathrm{PS}$ process exhibited uppermost rate constant value in comparison with the other processes. Hence, for the better interpretation, the synergy factor for PS/catalyst, UVA/catalyst, UVA/PS, and UVA/catalyst/PS processes was calculated by using the previously reported equations [46]. Accordingly, the synergy factor was found to be 1.1, 2, and 2.08 for PS/catalyst, UVA/catalyst, and UVA/PS processes. However according to Fig. $3 \mathrm{~b}$, the efficient catalyst in the presence of UVA resulted in the highest PS activation and consequently the synergy factor $\left(\frac{\mathrm{K}_{(\mathrm{UVA} / \text { Cataly st/PS })}}{\mathrm{K}_{(\mathrm{PS})}+\mathrm{K}_{(\mathrm{UVA} / \text { Cataly st }}}\right)$ of 4 . In the literature, the existence of the synergy effect was reported as proof of the high-performance process for the degradation of various water pollutants $[21,27]$. The main reason for the presence of the synergy factor and efficient SFL degradation to a greater extent can be related to the positive impact of the UVA-light and co-doped magnetite in the activation of persulfate. 

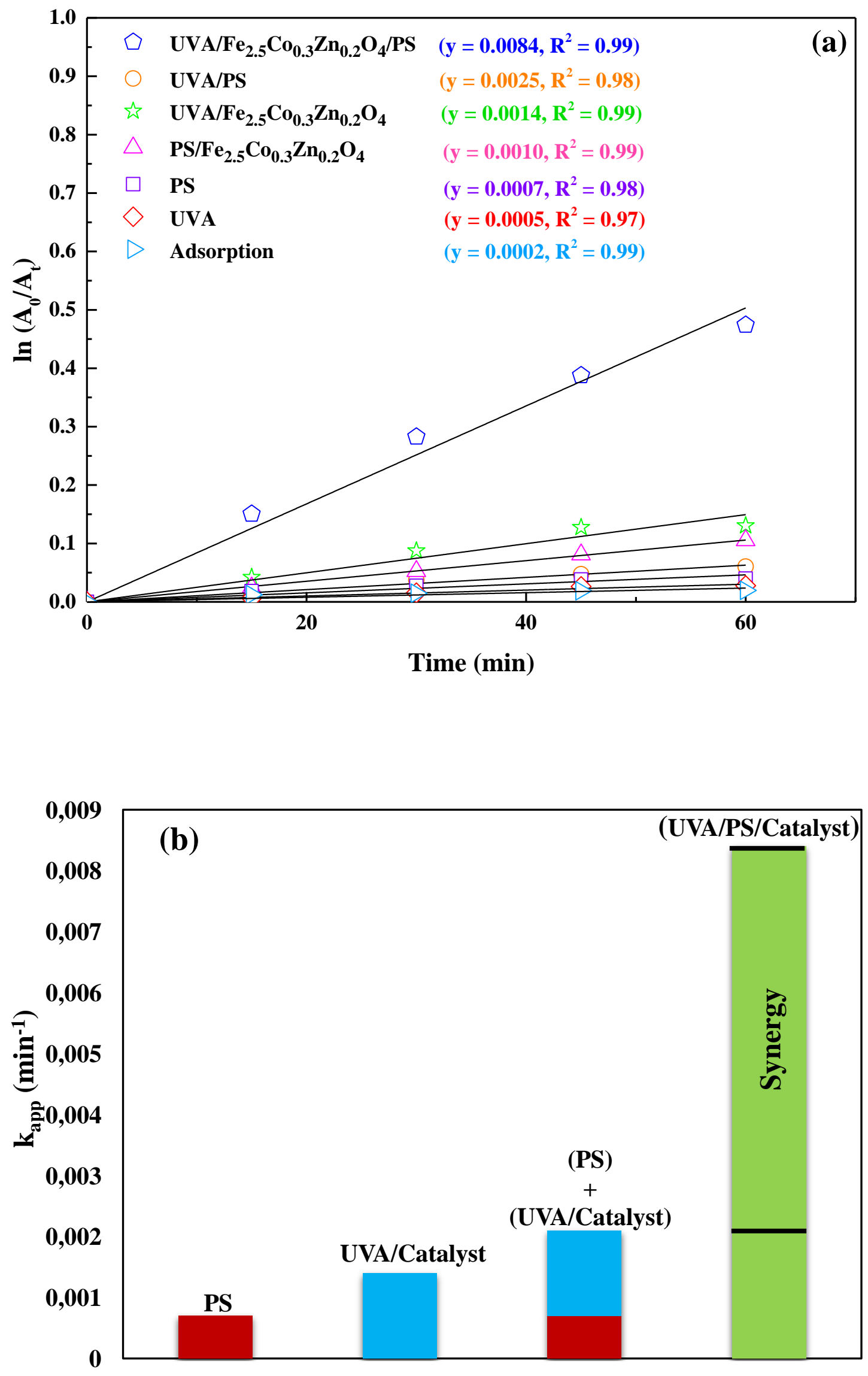
Fig. 3. (a) The kinetic profile of UVA/Fe $2.5 \mathrm{Co}_{0.3} \mathrm{Zn}_{0.2} \mathrm{O}_{4} / \mathrm{PS}$, and (b) evaluation of the synergy factor for $\mathrm{UVA} / \mathrm{Fe}_{2.5} \mathrm{Co}_{0.3} \mathrm{Zn}_{0.2} \mathrm{O}_{4} / \mathrm{PS}$ process compared with the individual processes. Experimental condition: $[\mathrm{SFL}]=25 \mu \mathrm{M}$, PS and HP concentration of $1 \mathrm{mM}$, photocatalyst concentration of $1 \mathrm{~g} \cdot \mathrm{L}^{-1}$, and $\mathrm{pH}=8$.

\subsection{The effect of different operational conditions}

The optimum operational condition is always of great importance due to an economical point of view; thereby, different parameters such as catalyst concentration, $\mathrm{pH}$, and oxidant concentration were tested (Fig. S9) and summarized in Table 3.

Table 3. Influence of main parameters on the degradation of SFL after 120 min of $\mathrm{UVA} / \mathrm{Fe}_{2.5} \mathrm{Co}_{0.3} \mathrm{Zn}_{0.2} \mathrm{O}_{4}$ process in the presence of PS and HP. Experimental condition: (a) effect of catalyst concentration $([\mathrm{SFL}]=25 \mu \mathrm{M}$, [PS] or $[\mathrm{HP}]=1 \mathrm{mM}$, and $\mathrm{pH}=8$ ), (b)impact of $\mathrm{pH}([\mathrm{SFL}]=25 \mu \mathrm{M},[\mathrm{PS}]$ or $[\mathrm{HP}]=1 \mathrm{mM}$, and catalyst concentration of 0.5 and 1 g. $\mathrm{L}^{-1}$ in the presence of PS and HP, respectively), and effect of oxidant concentration $\left([\mathrm{SFL}]=25 \mu \mathrm{M}, \mathrm{pH}=8\right.$, and catalyst concentration of 0.5 and $1 \mathrm{~g} \cdot \mathrm{L}^{-1}$ in the presence of (c) PS and (d) HP, respectively).

\begin{tabular}{|c|c|c|c|c|}
\hline \multirow{2}{*}{ Row } & \multirow{2}{*}{ Parameter } & \multirow{2}{*}{ Value } & \multicolumn{2}{|c|}{ DE (\%) } \\
\hline & & & $\mathrm{UVA} / \mathrm{Fe}_{2.5} \mathrm{Co}_{0.3} \mathrm{Zn}_{0.2} \mathrm{O}_{4} / \mathrm{PS}$ & $\mathrm{UVA} / \mathrm{Fe}_{2.5} \mathrm{Co}_{0.3} \mathrm{Zn}_{0.2} \mathrm{O}_{4} / \mathrm{HP}$ \\
\hline \multirow{5}{*}{ (a) } & \multirow{5}{*}{$\begin{array}{c}\text { Catalyst } \\
\text { concentration } \\
\left(\mathrm{g} \mathrm{L}^{-1}\right)\end{array}$} & 0.0 & 20.4 & 2.4 \\
\hline & & 0.5 & 55.1 & 14.1 \\
\hline & & 1.0 & 49.1 & 22.6 \\
\hline & & 1.5 & 42.8 & 24.8 \\
\hline & & 2.0 & 40.1 & 12.0 \\
\hline \multirow{5}{*}{ (b) } & \multirow{5}{*}{$\mathrm{pH}$} & 3.0 & 100.0 & 52.9 \\
\hline & & 6.0 & 91.7 & 27.1 \\
\hline & & 8.0 & 52.7 & 22.6 \\
\hline & & 10.0 & 45.9 & 16.8 \\
\hline & & 12.0 & 36.8 & 14.7 \\
\hline \multirow{2}{*}{ (c) } & \multirow{2}{*}[\mathrm{PS}]{$(\mathrm{mM})$} & 1.0 & 52.6 & - \\
\hline & & 2.0 & 72.1 & - \\
\hline
\end{tabular}




\begin{tabular}{ccccc}
\hline & $4.0^{*}$ & 70.0 & - \\
\cline { 2 - 4 } & 4.0 & 88.1 & - \\
\cline { 2 - 4 } & 8.0 & 100.0 & - \\
\hline \multirow{4}{*}{ (d) } & 1.0 & - & 22.6 \\
\cline { 3 - 5 } & {$[\mathrm{HP}](\mathrm{mM})$} & 2.0 & - & 32.9 \\
\cline { 3 - 5 } & & 4.0 & - & 41.9 \\
\cline { 2 - 4 } & & 8.0 & - & 33.0 \\
\hline
\end{tabular}

* Without catalyst

\subsubsection{Effect of photocatalyst concentration}

Selecting the best dose of the catalyst plays a key role in the photocatalytic degradation process from the chemical and economical perspectives. In doing so, a set of experiments were fulfilled using catalyst concentrations from 0.5 to $2.0 \mathrm{~g} \cdot \mathrm{L}^{-1}$ and the results were presented in Figs. S9 (a) and the related results are documented in Table 3. From Fig. S9 (a), it can be concluded that the photocatalytic performance of co-doped magnetite in the $\mathrm{UVA} / \mathrm{Fe}_{2.5} \mathrm{Co}_{0.3} \mathrm{Zn}_{0.2} \mathrm{O}_{4} / \mathrm{PS}$ process declines when the catalyst concentration increased from 0.5 to $2 \mathrm{~g} . \mathrm{L}^{-1}$. This trend can be attributed to the fact that the number of available active sites of the catalyst decreases due to the aggregation tendency of Co and $\mathrm{Zn}$ co-doped magnetite in the higher amounts. Moreover, the excess quantity of iron (II) can serve as the scavenging of sulfate radicals via Eq. (9) $[47,48]$.

$\mathrm{SO}_{4}{ }^{--}+\equiv \mathrm{Fe}(\mathrm{II}) \rightarrow \mathrm{SO}_{4}{ }^{2-}+\equiv \mathrm{Fe}(\mathrm{III})$

Fig. S9 (a) also reports the influence of catalyst concentration on the degradation efficiency using the $\mathrm{UVA} / \mathrm{Fe}_{2.5} \mathrm{Co}_{0.3} \mathrm{Zn}_{0.2} \mathrm{O}_{4} / \mathrm{HP}$ process. The increase in the catalyst concentration contributes to the enhancement of SFL removal efficiency until around 1.5 g.L ${ }^{1}$; however, the DE of SFL declined concurrent with further increase in the amount of the catalyst up to $2 \mathrm{~g} . \mathrm{L}^{-1}$. The DE increase of SFL can be related to the preparation of numerous amplified active sites for the generation of active hydroxyl radicals. With respect to the theory which has been interpreted in literature, exceed the amount of catalyst reduces the DE 
of SFL due to the aggregation of nanoparticles, and inhibition of hydroxyl radicals by a higher amount of iron.

Consequently, the catalyst concentration of $0.5 \mathrm{~g} . \mathrm{L}^{-1}$ was selected as the optimal value of catalyst concentration for the UVA/ $/ \mathrm{Fe}_{2.5} \mathrm{Co}_{0.3} \mathrm{Zn}_{0.2} \mathrm{O}_{4} / \mathrm{PS}$ process. However, the optimum catalyst concentration of $1 \mathrm{~g} . \mathrm{L}^{-1}$ was adopted in the $\mathrm{UVA} / \mathrm{Fe}_{2.5} \mathrm{Co}_{0.3} \mathrm{Zn}_{0.2} \mathrm{O}_{4} / \mathrm{HP}$ process, due to the slight difference in the obtained results for $1 \mathrm{~g} . \mathrm{L}^{-1}$ and $1.5 \mathrm{~g} \cdot \mathrm{L}^{-1}$.

\subsubsection{Effect of solution $\mathrm{pH}$}

The solution $\mathrm{pH}$ is one of the fundamental factors in the decomposition of the target pollutant [27]. Before performing the experiments related to this section, the point of zero charge of $\mathrm{Fe}_{2.5} \mathrm{Co}_{0.3} \mathrm{Zn}_{0.2} \mathrm{O}_{4}$ nanoparticles, the adsorption of SFL in the different $\mathrm{pH}$ values, and finally the $\mathrm{pk}_{\mathrm{a}}$ were studied and presented in Fig. S10. The $\mathrm{pH}_{\mathrm{pzc}}$ of Co and $\mathrm{Zn}$ co-doped magnetite was found to be 6.9. Besides, Figs. S10 (d) and (e) show that the stability of the SFL reduces synchronically with an increase in the $\mathrm{pH}$ of the solution regarding the obtained $\mathrm{pk}_{\mathrm{a}}$ of 4.2 and 6.4. Therefore, the higher adsorption of SFL on the surface of the catalyst was observed in the solution $\mathrm{pH}$ of 6 which is based on the electrostatic attraction of dissociated SFL and positively charged surface of the catalyst. On the other hand, a drop in the adsorption efficiency at higher $\mathrm{pH}$ of SFL on the surface of the catalyst can be interpreted by the existence of repulsive force.

Hence, in the next step, the solution $\mathrm{pH}$ was adjusted to $3,6,8,10$, and 12 to investigate its effect on the photocatalytic degradation process in the presence of PS and HP. The results are shown in Fig. S9 (b) and the related values were summarized in Table 3. The DE reduces in the presence of both oxidants by increasing the $\mathrm{pH}$ value of the solution which wellaccords with the results gained for the pollutant adsorption. Higher adsorption of SFL facilitated its reaction with the generated active radicals and holes [12]. Therefore, the 
increased adsorption trend of SFL on the catalyst surface led to the higher DE\% of SFL in the solution $\mathrm{pH}$ of 6 and 3. Additionally, it has been previously proved that the acidic solution promotes the release of transition metal ions such as $\mathrm{Fe}^{2+}$ in the solution which are the main activating agents for PS and HP [49]. On the other hand, the UVA/ $\mathrm{Fe}_{2.5} \mathrm{Co}_{0.3} \mathrm{Zn}_{0.2} \mathrm{O}_{4} / \mathrm{PS}$ demonstrated higher DE\% of SFL in the basic solution which can be assigned to the lower pH-dependence property of PS in comparison with HP [49]. However, the decrease in the DE of SFL at the strongly basic conditions can partly attributable to the reduction of $\mathrm{SO}_{4}{ }^{--}$and ${ }^{\circ} \mathrm{OH}$, and the decay of $\mathrm{H}_{2} \mathrm{O}_{2}$ into $\mathrm{O}_{2}$ and $\mathrm{H}_{2} \mathrm{O}[24,48]$.

In terms of the economic perspective and by considering the solution $\mathrm{pH}$ of the typical wastewaters which is around 7,5 - 8, the pursuing reactions were performed at a $\mathrm{pH}$ of 8 as the optimum value.

\subsubsection{Effect of oxidant concentration}

Fig. S9 (c) was to compare the effect of the pre-determined concentration of PS or HP on the photocatalytic degradation of $25 \mu \mathrm{M}$ of SFL. The attained results manifested that the rise in PS and HP concentration from $1 \mathrm{mM}$ to $8 \mathrm{mM}$ led to the promotion in the SFL degradation, being the best for PS with the $100 \%$ of DE, followed by HP with $58.8 \%$ of DE. Taking into account Eqs. 1-7, the increased degradation efficiency can be related to the production of more $\mathrm{SO}_{4}{ }^{--}$and ${ }^{\circ} \mathrm{OH}$ which can subsequently attack the model contaminant [50]. In comparison with the hydroxyl radicals, $\mathrm{SO}_{4}{ }^{--}$have a higher standard reduction potential at neutral $\mathrm{pH}$ which can further affirm the obtained results [51].

It is noteworthy that, no more enhancement was achieved when the PS concentration increased up to $8 \mathrm{mM}$. Moreover, in comparison with the sole $4 \mathrm{mM}$ PS, the presence of the catalyst and $4 \mathrm{mM}$ PS resulted in a slight increase in the DE (only 18\%). Therefore, the real advantage of using catalyst was not observed in the presence of $4 \mathrm{mM}$ PS. However, in 
section 3.2, it was revealed that in the integration of $1 \mathrm{mM} P S$, UVA, and $\mathrm{Fe}_{2.5} \mathrm{Co}_{0.3} \mathrm{Zn}_{0.2} \mathrm{O}_{4}$ nanoparticles the synergy factor was found to be 4 . Therefore, according to the literature review, a lower increase of the DE of SFL in the higher PS concentration can be attributed to the inhibiting effect of excessive PS on the produced sulfate radicals [52,53] during the $\mathrm{UVA} / \mathrm{Fe}_{2.5} \mathrm{Co}_{0.3} \mathrm{Zn}_{0.2} \mathrm{O}_{4} / \mathrm{PS}$ process. On the other hand, the TOC results which have been discussed in section 3.7 are good evidence for the positive effect of $\mathrm{Fe}_{2.5} \mathrm{Co}_{0.3} \mathrm{Zn}_{0.2} \mathrm{O}_{4}$ nanoparticles and 4mM PS to raise the TOC removal.

Therefore, in terms of economic potential, the ability to achieve higher degradation efficiency as well as higher TOC removal, $4 \mathrm{mM}$ of PS, and $8 \mathrm{mM}$ of $\mathrm{HP}$ were selected as more promising values for the operational experiments.

\subsection{Reusability of Co and Zn co-doped magnetite}

From the economic points of view, the reusability or stability of the catalysts in the catalyst-based degradation process is of great importance. Therefore, five recycling processes were carried out for 2 hours under the optimal condition and then the DE of SFL was calculated for each sample and displayed in Fig. 4. A slight reduction in the SFL degradation efficiency was observed hence proposing the stable structure and consequently unchanged properties of the co-doped magnetite for the promising oxidant-assisted photocatalytic degradation applications. 

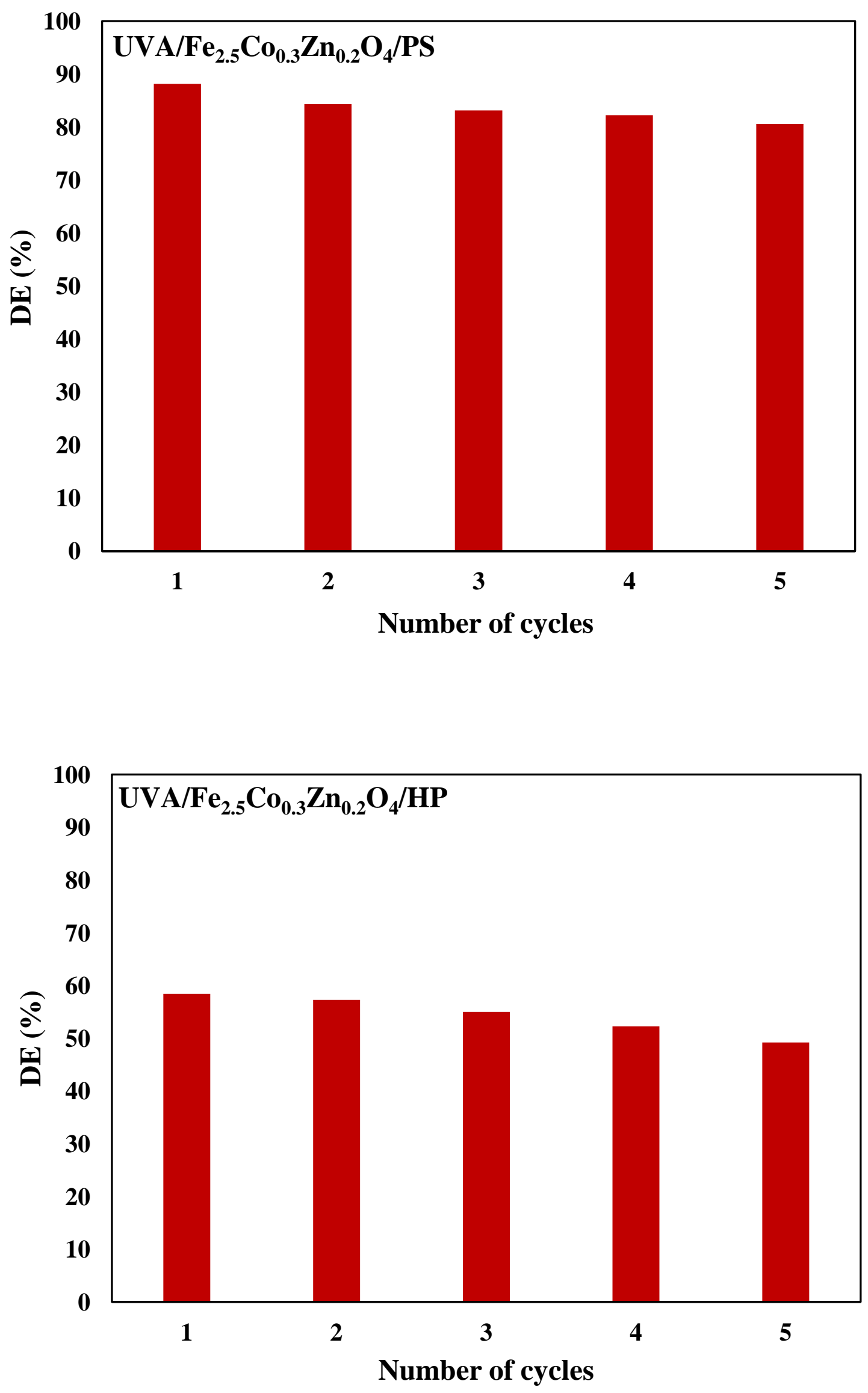
Fig. 4. Reusability of $\mathrm{Fe}_{2.5} \mathrm{Co}_{0.3} \mathrm{Zn}_{0.2} \mathrm{O}_{4}$ over five cycles of SFL degradation processes. Experimental condition: catalyst concentration of $0.5 \mathrm{~g} . \mathrm{L}^{-1}$ and $1.0 \mathrm{~g} . \mathrm{L}^{-1}$ for $\mathrm{UVA} / \mathrm{Fe}_{2.5} \mathrm{Co}_{0.3} \mathrm{Zn}_{0.2} \mathrm{O}_{4} / \mathrm{PS}$ or $\mathrm{UVA} / \mathrm{Fe}_{2.5} \mathrm{Co}_{0.3} \mathrm{Zn}_{0.2} \mathrm{O}_{4} / \mathrm{HP}$ process respectively, [SFL] = 25

$$
\mu \mathrm{M},[\mathrm{PS}] \text { or }[\mathrm{HP}]=1 \mathrm{mM} \text {, and } \mathrm{pH}=8 \text {. }
$$

Moreover, the co-doped magnetite nanoparticles were collected after 5 cycles and characterized by the XPS analysis. The XPS survey spectrum of the utilized photocatalyst after 5 cycles of the degradation process was almost the same as those of fresh nanoparticles (Fig. S11). This can be attributed to the no significant variation in the surface composition of the used nanoparticles. For further evaluation of the catalyst stability before and after the degradation process, the ICP analysis was used to determine the concentration of dissolved metal ions in the solution media (Table 4). Given that, after starting the $\mathrm{UVA} / \mathrm{Fe}_{2.5} \mathrm{Co}_{0.3} \mathrm{Zn}_{0.2} \mathrm{O}_{4} / \mathrm{PS}$ process, the dissolved concentration of $\mathrm{Fe}$, $\mathrm{Co}$, and $\mathrm{Zn}$ ions was achieved to be $0.018,0.0032,0.016 \mathrm{mg} . \mathrm{L}^{-1}$. Alike to the previous process in the $\mathrm{UVA} / \mathrm{Fe}_{2.5} \mathrm{Co}_{0.3} \mathrm{Zn}_{0.2} \mathrm{O}_{4} / \mathrm{HP}$ treatment process, the catalyst demonstrated a slight increase in the metal ions release. The slight increment in the concentration of the dissolved ions is negligibly contemplating the used catalyst concentration of $0.5 \mathrm{~g} . \mathrm{L}^{-1}$ and $1 \mathrm{~g} . \mathrm{L}^{-1}$ in the case of using PS and HP, respectively. Moreover, according to the World Health Organization (WHO) [54], the maximal permissible concentration of iron, cobalt, and zinc are, $0.1 \mathrm{mg} . \mathrm{L}^{-1}$, $5 \mu \mathrm{g} . \mathrm{L}^{-1}$, and $5 \mathrm{mg} . \mathrm{L}^{-1}$, respectively. Thereby, owing to the fact that the results are lower than the standard values, the released ions are not harmful to health.

Table 4. The ICP results of the dissolved metal ions after 120 min of different processes. Experimental condition: $[\mathrm{SFL}]=25 \mu \mathrm{M},[\mathrm{PS}]=4 \mathrm{mM},[\mathrm{HP}]=8 \mathrm{mM}, \mathrm{pH}=8$, catalyst concentration of 0.5 and 1 g. $\mathrm{L}^{-1}$ in the presence of PS and HP, respectively. 


\begin{tabular}{cccc}
\hline \multirow{2}{*}{ Processes } & \multicolumn{3}{c}{ Metal ion concentration mg. $\mathbf{L}^{-1}$} \\
\cline { 2 - 4 } & Fe & Co & Zn \\
\hline UVA/Fe ${ }_{2.5} \mathrm{Co}_{0.3} \mathrm{Zn}_{0.2} \mathrm{O}_{4} / \mathrm{PS}$ & 0.018 & 0.0032 & 0.016 \\
\hline $\mathrm{UVA} / \mathrm{Fe}_{2.5} \mathrm{Co}_{0.3} \mathrm{Zn}_{0.2} \mathrm{O}_{4} / \mathrm{HP}$ & 0.02 & 0.0039 & 0.028 \\
\hline
\end{tabular}

\subsection{The predominate radical species involving in the degradation process}

The scavenger compounds are widely used for inhibiting the free active radicals which contribute to the degradation of organic pollutants [11]. Consequently, the dominant radical species ( $\mathrm{OH}$ vs. $\mathrm{SO}_{4}{ }^{-{ }^{-}}$) were trapped by applying $10 \mathrm{mM}$ of tert-butyl alcohol (TBA) and isopropyl alcohol (IPA). Benzoquinone (BQ), Potassium iodide (KI) were also used to quench $\mathrm{O}_{2}{ }^{--}$and $\mathrm{h}^{+}$, respectively $[55,56]$. In the present work, the effect of different scavengers on the degradation of SFL was assessed in the presence of $\mathrm{UVA} / \mathrm{Fe}_{2.5} \mathrm{Co}_{0.3} \mathrm{Zn}_{0.2} \mathrm{O}_{4} / \mathrm{PS}$ and $\mathrm{UVA} / \mathrm{Fe}_{2.5} \mathrm{Co}_{0.3} \mathrm{Zn}_{0.2} \mathrm{O}_{4} / \mathrm{HP}$ processes and the results were presented in Figs. 5a and 5b, respectively. According to Fig. 5a, SFL degradation was retarded in the presence of IPA and TBA wherein the DE was only $40 \%$ and $65 \%$. As TBA is not a proper agent for quenching sulfate radicals; thereby, $24 \%$ of DE inhibition can be attributed to the presence of ${ }^{\circ} \mathrm{OH}$ in $\mathrm{UVA} / \mathrm{Fe}_{2.5} \mathrm{Co}_{0.3} \mathrm{Zn}_{0.2} \mathrm{O}_{4} / \mathrm{PS}$ process (Eqs. 1-7). The presence of BQ and KI led to a decrease in the DE, indicating the participation of $\mathrm{O}_{2}{ }^{--}$and $\mathrm{h}^{+}$ in the degradation of target pollutants. Although KI has used as the hole scavenger in the published papers, KI can also react with the PS which in turn can have a negative effect in the $\mathrm{DE}$ of $\mathrm{SFl}$ [57]. However, among the detected reactive radicals, $\mathrm{SO}_{4}{ }^{--}$and ${ }^{\circ} \mathrm{OH}$ were the main contributed reactive radical species in the UVA/Fe ${ }_{2.5} \mathrm{Co}_{0.3} \mathrm{Zn}_{0.2} \mathrm{O}_{4} / \mathrm{PS}$ process.

Moreover, all the scavengers showed an inhibiting effect in the degradation efficiency of SFL by $\mathrm{UVA} / \mathrm{Fe}_{2.5} \mathrm{Co}_{0.3} \mathrm{Zn}_{0.2} \mathrm{O}_{4} / \mathrm{HP}$ process, wherein; the DE was changed from $58 \%$ to $39.6 \%$ and $43.5 \%$ in the presence of TBA and IPA, respectively. Besides the confirmation of dominated ${ }^{\circ} \mathrm{OH}$ participation in the $\mathrm{UVA} / \mathrm{Fe}_{2.5} \mathrm{Co}_{0.3} \mathrm{Zn}_{0.2} \mathrm{O}_{4} / \mathrm{HP}$ process for the degradation of 
SFL, it is well proved that under the same operational condition the production of ${ }^{\circ} \mathrm{OH}$ in the presence of HP was lower in comparison with PS.
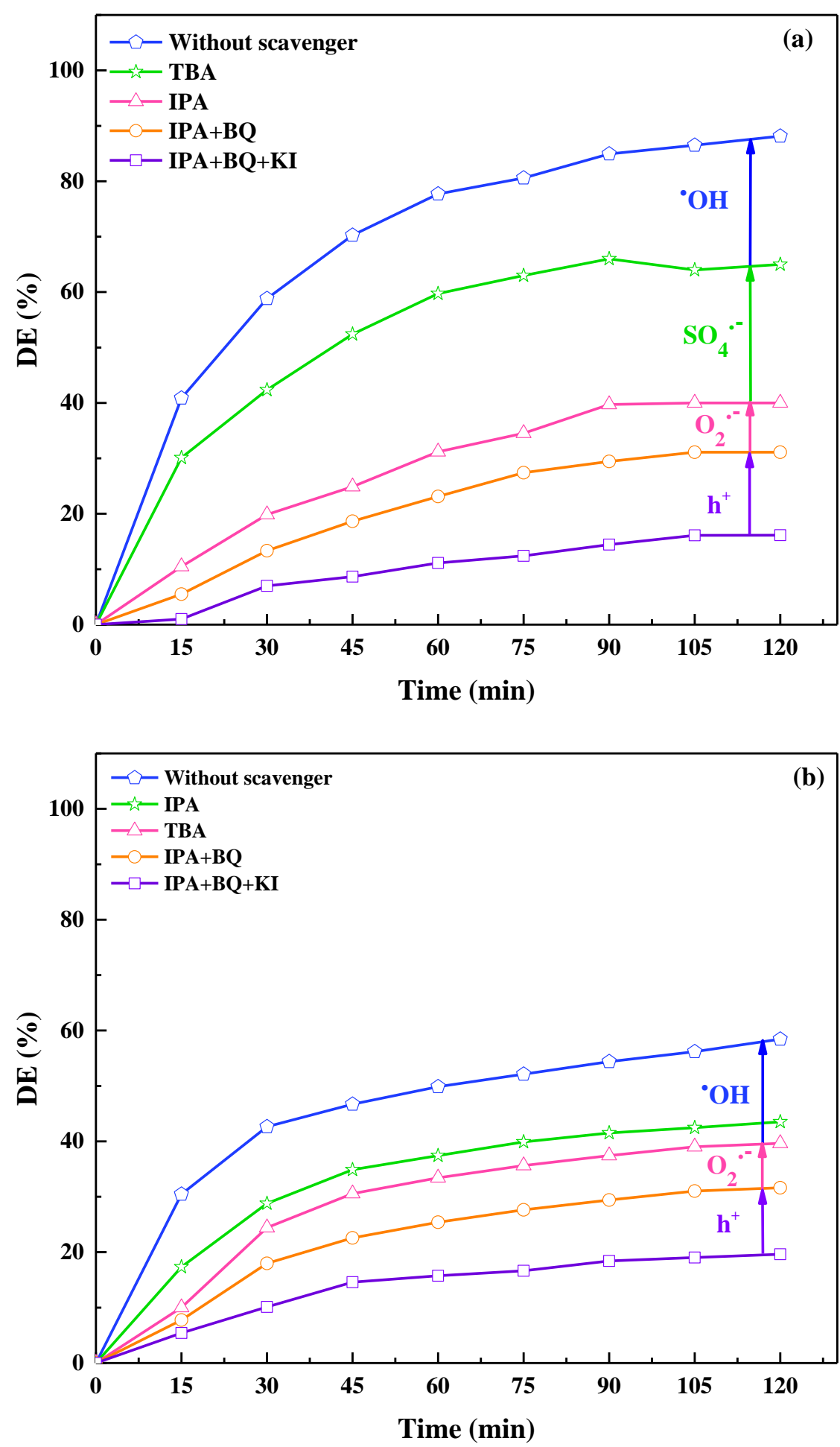

Fig. 5. The impact of adding the scavengers on the DE of SFL under the (a) $\mathrm{UVA} / \mathrm{Fe}_{0.5} \mathrm{Co}_{0.3} \mathrm{Zn}_{0.2} \mathrm{O}_{4} / \mathrm{PS}$ and (b) $\mathrm{UVA} / \mathrm{Fe}_{0.5} \mathrm{Co}_{0.3} \mathrm{Zn}_{0.2} \mathrm{O}_{4} / \mathrm{HP}$ processes. Experimental 
condition: $[\mathrm{SFL}]=25 \mu \mathrm{M},[\mathrm{PS}]=4 \mathrm{mM},[\mathrm{HP}]=8 \mathrm{mM}, \mathrm{pH}=8$, [scavenger $]=10 \mathrm{mM}$, photocatalyst concentration of 0.5 g. $\mathrm{L}^{-1}$, and 1.0 g. $\mathrm{L}^{-1}$ for $\mathrm{UVA} / \mathrm{Fe}_{0.5} \mathrm{Co}_{0.3} \mathrm{Zn}_{0.2} \mathrm{O}_{4} / \mathrm{PS}$, and $\mathrm{UVA} / \mathrm{Fe}_{0.5} \mathrm{Co}_{0.3} \mathrm{Zn}_{0.2} \mathrm{O}_{4} / \mathrm{HP}$, respectively.

\subsection{Assessing the DE of SFL in real wastewater matrix}

The photocatalytic degradation in the presence of PS and HP was carried out in the real wastewater matrix to approximate the artificial results to the real condition. Indeed, the real wastewater comprised of different kinds of inorganic and organic compounds that compete to react with the reactive oxygen species [58]. As it is stated in the literature, the available impurities in the real wastewater quench the active oxidizing radicals which in turn cause the lower degradation performance [59]. Therefore, in order to not ignore the effect of these kinds of impurities on our achieved results in the ultrapure water, the same sequenced experiments were conducted for the photocatalytic degradation of $25 \mu \mathrm{M}$ of SFL in $100 \mathrm{~mL}$ of the real wastewater with the characterization values presented in our previously published paper [60]. According to Fig. 6, it is clear that the DE for the applied process in the presence of PS and HP was $67.2 \%$ and $32.9 \%$, respectively; whereas, the respective results in the ultrapure water was $88.1 \%$ and $58.4 \%$. The lower degradation efficiency observed in wastewater can be assigned to the presence of organic matter and inorganic ions that can react with sulfate and hydroxyl radicals [61]. Moreover, UVA/ $\mathrm{Fe}_{2.5} \mathrm{Co}_{0.3} \mathrm{Zn}_{0.2} \mathrm{O}_{4} / \mathrm{PS}$ process illustrated a more robust efficiency than $\mathrm{UVA} / \mathrm{Fe}_{2.5} \mathrm{Co}_{0.3} \mathrm{Zn}_{0.2} \mathrm{O}_{4} / \mathrm{HP}$ process for $\mathrm{SFL}$ degradation in the real wastewater, indicating a more applicable approach for the higher degradation of organic water pollutants. 

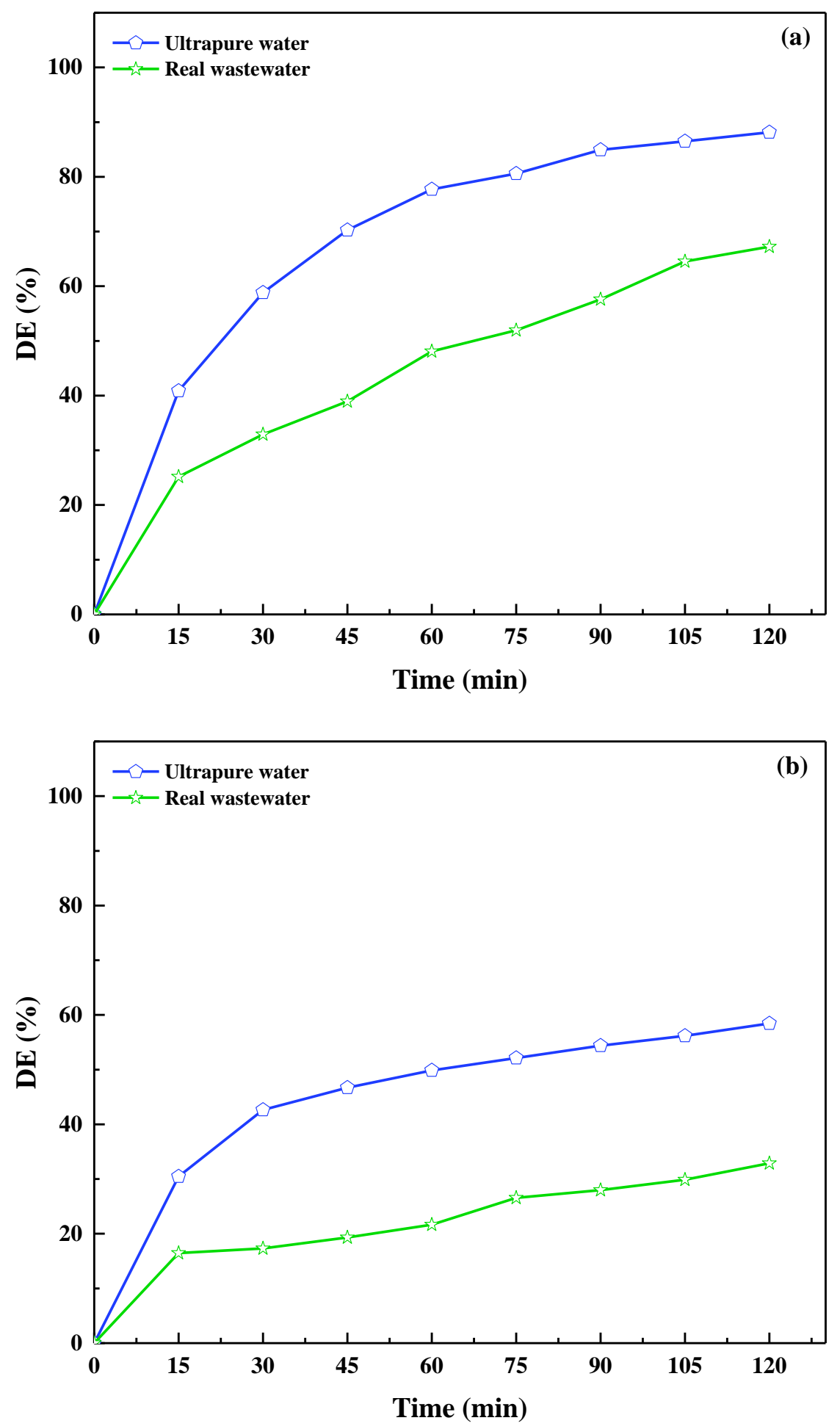

Fig. 6. The DE of SFL in ultrapure water and wastewater under the (a)

UVA/ $/ \mathrm{Fe}_{0.5} \mathrm{Co}_{0.3} \mathrm{Zn}_{0.2} \mathrm{O}_{4} / \mathrm{PS}$ and (b) UVA/ $\mathrm{Fe}_{0.5} \mathrm{Co}_{0.3} \mathrm{Zn}_{0.2} \mathrm{O}_{4} / \mathrm{HP}$ processes. Experimental condition: $[\mathrm{SFL}]=25 \mu \mathrm{M},[\mathrm{PS}]=4 \mathrm{mM},[\mathrm{HP}]=8 \mathrm{mM}, \mathrm{pH}=8$, photocatalyst concentration of 0.5 g.L $\mathrm{L}^{-1}$, and 1.0 g. $\mathrm{L}^{-1}$ for UVA/Fe $\mathrm{F}_{0.5} \mathrm{Co}_{0.3} \mathrm{Zn}_{0.2} \mathrm{O}_{4} / \mathrm{PS}$, and $\mathrm{UVA} / \mathrm{Fe}_{0.5} \mathrm{Co}_{0.3} \mathrm{Zn}_{0.2} \mathrm{O}_{4} / \mathrm{HP}$, respectively. 


\subsection{Assessing the mineralization of SFL during the processes}

Mineralization of the organic compounds into water, carbon dioxide, and other nontoxic intermediates have been the main target of the researchers. Therefore, in the direction of thorough mineralization of SFL, a set of experiments were fulfilled under the optimal condition for $1,2,5,15,30$, and $60 \mathrm{~h}$ of degradation time and finally their TOC removal was measured and reported in Fig. S12. As the results indicate, the UVA/Fe ${ }_{2.5} \mathrm{Co}_{0.3} \mathrm{Zn}_{0.2} \mathrm{O}_{4} / \mathrm{PS}$ process manifested a proper TOC removal trend and consequently higher mineralization of SFL. Moreover, the results illustrate that the presence of catalyst enhanced the TOC removal from $53.21 \%$ to $85.08 \%$ after $15 \mathrm{~h}$ of UVA/PS and $\mathrm{UVA} / \mathrm{Fe}_{2.5} \mathrm{Co}_{0.3} \mathrm{Zn}_{0.2} \mathrm{O}_{4} / \mathrm{PS}$ process, respectively. The main reasons for the increased TOC removal can be attributed to the higher photocatalytic efficiency of co-doped magnetite, and efficient activation of PS in the presence of photocatalysts.

\subsection{Assessing the toxicity of the produced by products}

According to the previous sections, the UVA/ $\mathrm{Fe}_{2.5} \mathrm{Co}_{0.3} \mathrm{Zn}_{0.2} \mathrm{O}_{4} / \mathrm{PS}$ process demonstrated better performance for the degradation of model pollutants due to the simultaneous production of sulfate and hydroxyl radicals. Hence, the toxicity of the probably produced byproducts was assessed to further investigate the ecological efficiency of the utilized processes.

Due to the high rate of growth, and great sensitivity to the numerous kinds of water pollutants, the aquatic species such as Lemna minor were widely applied for determining the water pollutant toxicity [28]. Therefore, in the present research Lemna minor species were exposed to the reference solution, untreated SFL solution, and SFL solutions treated for 60 and 120 min under the optimal condition. Fig. 7 illustrate that Lemna minor fronds were got 
blenched in the untreated solution indicating the toxicity of SFL for inhibiting their metabolic activity. However, comparing with the reference sample, the collected solution after $120 \mathrm{~min}$ of the UVA/ $\mathrm{Fe}_{2.5} \mathrm{Co}_{0.3} \mathrm{Zn}_{0.2} \mathrm{O}_{4} / \mathrm{PS}$ degradation process showed almost no change in the color and visual characters of the fronds and they maintained their growth as well. Consequently, the toxicity of treated solution was declined due to the attack of available radicals to the toxic SFL and probable intermediates and converting them to non-toxic compounds. The obtained results encourage to put forward the UVA/Fe $2.5 \mathrm{Co}_{0.3} \mathrm{Zn}_{0.2} \mathrm{O}_{4} / \mathrm{PS}$ process as an appropriate degradation process for the outstanding removal of newly emerged water pollutants.
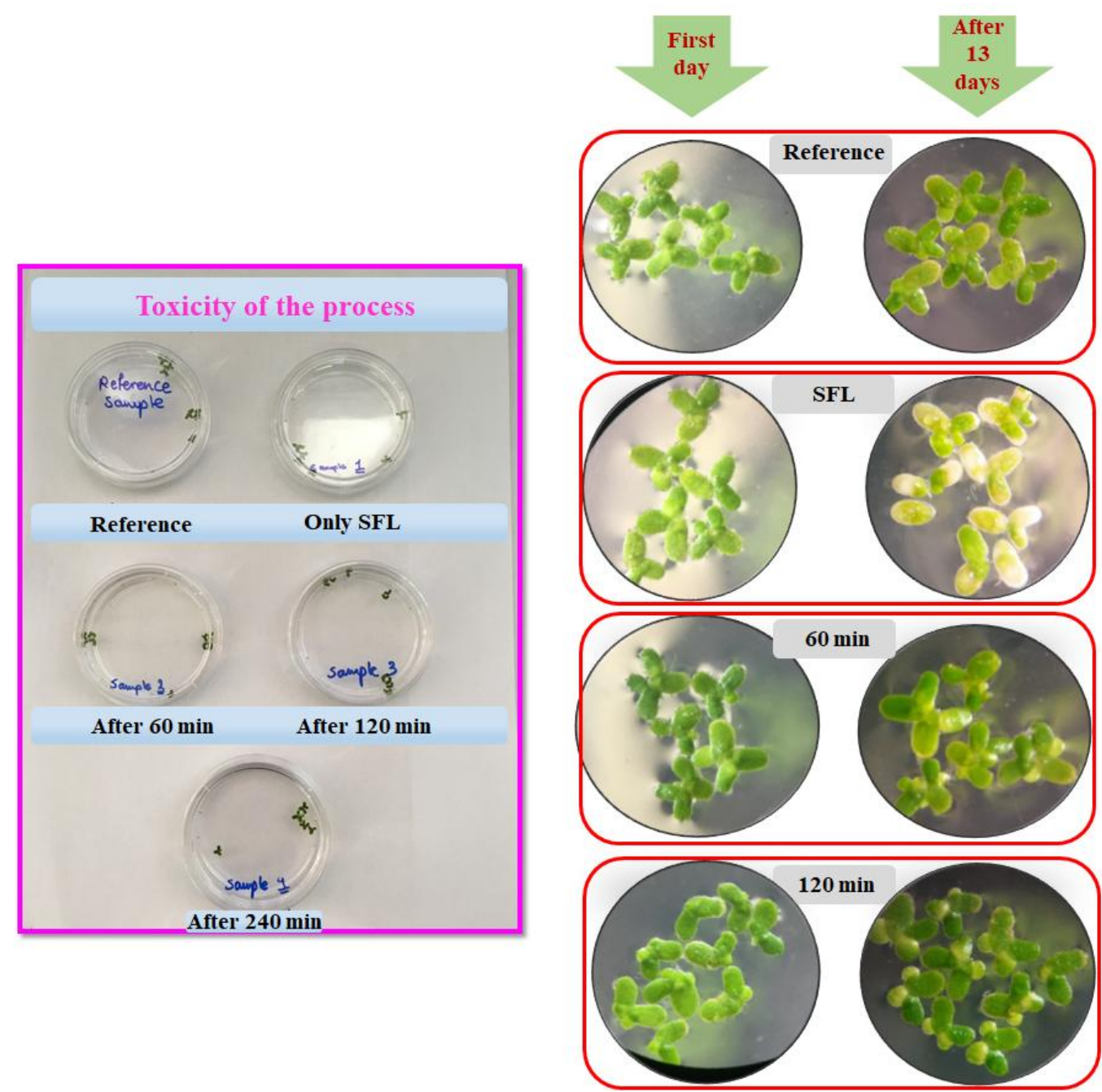

Fig. 7. The visual alteration of L. minor in reference solution, untreated SFL solution, and treated samples after $60 \mathrm{~min}$, and $120 \mathrm{~min}$ of $\mathrm{UVA} / \mathrm{Fe}_{2.5} \mathrm{Co}_{0.3} \mathrm{Zn}_{0.2} \mathrm{O}_{4} / \mathrm{PS}$ process. 


\section{Conclusion}

In the present work, the cubic pure $\mathrm{Fe}_{3} \mathrm{O}_{4}, \mathrm{Fe}_{2.7} \mathrm{Zn}_{0.3} \mathrm{O}_{4}, \mathrm{Fe}_{2.7} \mathrm{Co}_{0.3} \mathrm{O}_{4}$, and $\mathrm{Fe}_{2.5} \mathrm{Co}_{0.3} \mathrm{Zn}_{0.2} \mathrm{O}_{4}$ were synthesized, characterized and used for the activation of persulfate (PS) and hydrogen peroxide (HP) under UVA irradiation. Comparing with the other processes, $\mathrm{UVA} / \mathrm{Fe}_{2.5} \mathrm{Co}_{0.3} \mathrm{Zn}_{0.2} \mathrm{O}_{4} / \mathrm{PS}$ displayed a superior performance for the degradation of SFL as the newly emerged pollutant from water. The effect of different physicochemical parameters as well as the dominant produced reactive radicals during the $\mathrm{UVA} / \mathrm{Fe}_{2.5} \mathrm{Co}_{0.3} \mathrm{Zn}_{0.2} \mathrm{O}_{4} / \mathrm{PS}$ process was assessed. Additionally, in the real wastewater and under $120 \mathrm{~min}$ of the $\mathrm{UVA} / \mathrm{Fe}_{2.5} \mathrm{Co}_{0.3} \mathrm{Zn}_{0.2} \mathrm{O}_{4} / \mathrm{PS}$ process, $67.2 \%$ of SFL degradation was achieved. Therefore, by considering the great capacity in the mineralization of SFL ( $85 \%$ after $15 \mathrm{~h}$ ), production of the nontoxic intermediates during the degradation, and the $\mathrm{pH}$-independence properties, $\mathrm{UVA} / \mathrm{Fe}_{2.5} \mathrm{Co}_{0.3} \mathrm{Zn}_{0.2} \mathrm{O}_{4} / \mathrm{PS}$ process can be as the promising process for the degradation of other sever water pollutants. Eventually, we envision that the future studies on the activation of oxidants can be benefited from the obtained results of the present paper to design other effective processes to gain the thorough mineralization of various water pollutants in a short time.

\section{Acknowledgments}

The authors acknowledge the French Embassy in Iran for the financial support of Arezou Fazli during her stay in France. The authors thank Mhammed Banbakkar for conducting the ICP analysis and to Guillaume Monier for accomplishing the XPS analysis. 


\section{References}

[1] L. Charuaud, E. Jarde, A. Jaffrezic, M. F. Thomas, B. Le Bot, Veterinary pharmaceutical residues from natural water to tap water: Sales, occurrence and fate, J. Hazard. Mater. 361 (2019) 169-186. https://doi.org/10.1016/j.jhazmat.2018.08.075.

[2] J. Zhao, Q. He, X. Zhang, X. Guo, Q. Song, Y. Liu, B. Yao, Q. Zhang, D.D. Dionysiou, Fabrication of $\mathrm{CQDs} / \mathrm{Bi}_{5} \mathrm{Nb}_{3} \mathrm{O}_{15}$ nanocomposites for photocatalytic degradation of veterinary pharmaceutical sarafloxacin, Catal. Today. (2019). https://doi.org/10.1016/j.cattod.2019.05.006.

[3] O. Bajt, G. Mailhot, M. Bolte, Degradation of dibutyl phthalate by homogeneous photocatalysis with Fe(III) in aqueous solution, Appl. Catal. B Environ. 33 (2001) 239248. https://doi.org/10.1016/S0926-3373(01)00179-5.

[4] K.V. Karthik, Ch.V. Reddy, K.R. Reddy, R. Ravishankar, G. Sanjeev, R.V. Kulkarni, N.P. Shetti, A.V. Raghu, Barium titanate nanostructures for photocatalytic hydrogen generation and photodegradation of chemical pollutants, J. Mater. Sci. Mater. Electron. 30 (2019) 20646-20653. https://doi.org/10.1007/s10854-019-02430-6.

[5] Ch.V. Reddy, I.N. Reddy, V.V.N. Harish, K.R. Reddy, N.P. Shetti, J. Shim, T.M. Aminabhavi, Efficient removal of toxic organic dyes and photoelectrochemical properties of iron-doped zirconia nanoparticles, Chemosphere. 239 (2020) 124766. https://doi.org/10.1016/j.chemosphere.2019.124766.

[6] R. Koutavarapu, B. Babu, C.V. Reddy, I.N. Reddy, K.R. Reddy, M.C. Rao, T.M. Aminabhavi, M. Cho, D. Kim, J. Shim, $\mathrm{ZnO}$ nanosheets-decorated $\mathrm{Bi}_{2} \mathrm{WO}_{6}$ nanolayers as efficient photocatalysts for the removal of toxic environmental pollutants and photoelectrochemical solar water oxidation, J. Environ. Manage. 265 (2020) 110504. https://doi.org/10.1016/j.jenvman.2020.110504. 
[7] K. Qi, Y. Xie, R. Wang, S. Liu, Z. Zhao, Electroless plating Ni-P cocatalyst decorated g- $\mathrm{C}_{3} \mathrm{~N}_{4}$ with enhanced photocatalytic water splitting for $\mathrm{H}_{2}$ generation, Appl. Surf. Sci. 466 (2019) 847-853. https://doi.org/10.1016/j.apsusc.2018.10.037.

[8] X. Yang, W. Chen, J. Huang, Y. Zhou, Y. Zhu, C. Li, Rapid degradation of methylene blue in a novel heterogeneous $\mathrm{Fe}_{3} \mathrm{O}_{4} @ \mathrm{rGO} @ \mathrm{TiO}_{2}$-catalyzed photo-Fenton system, Sci. Rep. 5 (2015) 1-10. https://doi.org/10.1038/srep10632.

[9] G. Ren, M. Zhou, P. Su, W. Yang, X. Lu, Y. Zhang, Simultaneous sulfadiazines degradation and disinfection from municipal secondary effluent by a flow-through electro-Fenton process with graphene-modified cathode, J. Hazard. Mater. 368 (2019) 830-839. https://doi.org/10.1016/j.jhazmat.2019.01.109.

[10] A. Fiorentino, B. Esteban, J.A. Garrido-Cardenas, K. Kowalska, L. Rizzo, A. Aguera, J.A.S. Pérez, Effect of solar photo-Fenton process in raceway pond reactors at neutral $\mathrm{pH}$ on antibiotic resistance determinants in secondary treated urban wastewater, J. Hazard. Mater. 378 (2019) 120737. https://doi.org/10.1016/j.jhazmat.2019.06.014.

[11] T.S. Rad, A. Khataee, S. Rahim Pouran, Synergistic enhancement in photocatalytic performance of Ce (IV) and Cr (III) co-substituted magnetite nanoparticles loaded on reduced graphene oxide sheets, J. Colloid Interface Sci. 528 (2018) 248-262. https://doi.org/10.1016/j.jcis.2018.05.087.

[12] R. Hassandoost, S.R. Pouran, A. Khataee, Y. Orooji, S.W. Joo, Hierarchically structured ternary heterojunctions based on $\mathrm{Ce}^{3+} / \mathrm{Ce}^{4+}$ modified $\mathrm{Fe}_{3} \mathrm{O}_{4}$ nanoparticles anchored onto graphene oxide sheets as magnetic visible-light-active photocatalysts for decontamination of oxytetracycline, J. Hazard. Mater. 376 (2019) 200-211. https://doi.org/10.1016/j.jhazmat.2019.05.035.

[13] C.V. Reddy, I.N. Reddy, K. Ravindranadh, K.R. Reddy, N.P. Shetti, D. Kim, J. Shim, T.M. Aminabhavi, Copper-doped $\mathrm{ZrO}_{2}$ nanoparticles as high-performance catalysts for 
efficient removal of toxic organic pollutants and stable solar water oxidation, J. Environ. Manage. 260 (2020) 110088. https://doi.org/10.1016/j.jenvman.2020.110088.

[14] S. Wang, B. Zhu, M. Liu, L. Zhang, J. Yu, M. Zhou, Direct Z-scheme ZnO/CdS hierarchical photocatalyst for enhanced photocatalytic $\mathrm{H}_{2}$-production activity, Appl. Catal. B Environ. 243 (2019) 19-26. https://doi.org/10.1016/j.apcatb.2018.10.019.

[15] F. Wang, X. Yu, M. Ge, S. Wu, One-step synthesis of $\mathrm{TiO}_{2} / \gamma-\mathrm{Fe}_{2} \mathrm{O}_{3} / \mathrm{GO}$ nanocomposites for visible light-driven degradation of ciprofloxacin, Chem. Eng. J. (2019) 123381. https://doi.org/10.1016/j.cej.2019.123381.

[16] I. Ibrahim, A. Kaltzoglou, C. Athanasekou, F. Katsaros, E. Devlin, A.G. Kontos, N. Ioannidis, M. Perraki, P. Tsakiridis, L. Sygellou, M. Antoniadou, P. Falaras, Magnetically separable $\mathrm{TiO}_{2} / \mathrm{CoFe}_{2} \mathrm{O}_{4} / \mathrm{Ag}$ nanocomposites for the photocatalytic reduction of hexavalent chromium pollutant under UV and artificial solar light, Chem. Eng. J. 381 (2020) 122730. https://doi.org/10.1016/j.cej.2019.122730.

[17] X.S. Nguyen, G. Zhang, X. Yang, Mesocrystalline Zn-Doped $\mathrm{Fe}_{3} \mathrm{O}_{4}$ Hollow Submicrospheres: Formation Mechanism and Enhanced Photo-Fenton Catalytic Performance, ACS Appl. Mater. Interfaces. 9 (2017) 8900-8909. https://doi.org/10.1021/acsami.6b16839.

[18] P.M. Anjana, M.R. Bindhu, M. Umadevi, R.B. Rakhi, Antimicrobial, electrochemical and photo catalytic activities of $\mathrm{Zn}$ doped Fe3O4 nanoparticles, J. Mater. Sci. Mater. Electron. 29 (2018) 6040-6050. https://doi.org/10.1007/s10854-018-8578-2.

[19] N.F. Andrade Neto, L.E. Nascimento, M. Correa, F. Bohn, M.R.D. Bomio, F.V. Motta, Characterization and photocatalytic application of $\mathrm{Ce}^{4+}, \mathrm{Co}^{2+}, \mathrm{Mn}^{2+}$ and $\mathrm{Ni}^{2+}$ doped $\mathrm{Fe}_{3} \mathrm{O}_{4}$ magnetic nanoparticles obtained by the co-precipitation method, Mater. Chem. Phys. 242 (2020) 122489. https://doi.org/10.1016/j.matchemphys.2019.122489. 
[20] J. Qi, H. Lan, R. Liu, H. Liu, J. Qu, Efficient Microcystis aeruginosa removal by moderate photocatalysis-enhanced coagulation with magnetic $\mathrm{Zn}$-doped $\mathrm{Fe}_{3} \mathrm{O}_{4}$ particles, Water Res. 171 (2020) 115448. https://doi.org/10.1016/j.watres.2019.115448.

[21] T.S. Rad, A. Khataee, S. Rahim Pouran, Synergistic enhancement in photocatalytic performance of $\mathrm{Ce}$ (IV) and $\mathrm{Cr}$ (III) co-substituted magnetite nanoparticles loaded on reduced graphene oxide sheets, J. Colloid Interface Sci. 528 (2018) 248-262. https://doi.org/10.1016/j.jcis.2018.05.087.

[22] Z. Chen, Y. Zheng, Y. Liu, W. Zhang, Y. Wang, X. Guo, X. Tang, Y. Zhang, Z. Wang, T. Zhang, Magnetic Mn-Doped $\mathrm{Fe}_{3} \mathrm{O}_{4}$ hollow Microsphere/RGO heterogeneous PhotoFenton Catalyst for high efficiency degradation of organic pollutant at neutral $\mathrm{pH}$, $\begin{array}{lllll}\text { Mater. } & \text { Chem. } & \text { Phys. } & 238 & \text { (2019) }\end{array}$ https://doi.org/10.1016/j.matchemphys.2019.121893.

[23] X. Wang, W. Dong, M. Brigante, G. Mailhot, Hydroxyl and sulfate radicals activated by Fe(III)-EDDS/UV: Comparison of their degradation efficiencies and influence of critical parameters, Appl. Catal. B Environ. $245 \quad$ (2019) 271-278. https://doi.org/10.1016/j.apcatb.2018.12.052.

[24] T. Sadeghi Rad, A. Khataee, S.R. Pouran, S.W. Joo, The key role of free radicals generated from activation of $\mathrm{H}_{2} \mathrm{O}_{2}, \mathrm{~S}_{2} \mathrm{O}_{8}{ }^{2-}$ and ozone over chromium/cerium co-doped magnetite nanoparticles, Sep. Purif. Technol. $239 \quad$ (2020) 116538. https://doi.org/10.1016/j.seppur.2020.116538.

[25] Y. Zhong, X. Liang, W. Tan, Y. Zhong, H. He, J. Zhu, P. Yuan, Z. Jiang, A comparative study about the effects of isomorphous substitution of transition metals ( $\mathrm{Ti}, \mathrm{Cr}, \mathrm{Mn}, \mathrm{Co}$ and Ni) on the UV/Fenton catalytic activity of magnetite, J. Mol. Catal. Chem. 372 (2013) 29-34. https://doi.org/10.1016/j.molcata.2013.01.038. 
[26] Y. Ren, L. Lin, J. Ma, J. Yang, J. Feng, Z. Fan, Sulfate radicals induced from peroxymonosulfate by magnetic ferrospinel $\mathrm{MFe}_{2} \mathrm{O}_{4}(\mathrm{M}=\mathrm{Co}, \mathrm{Cu}, \mathrm{Mn}$, and $\mathrm{Zn})$ as heterogeneous catalysts in the water, Appl. Catal. B Environ. 165 (2015) 572-578. https://doi.org/10.1016/j.apcatb.2014.10.051.

[27] A. Khataee, A. Fazli, M. Fathinia, F. Vafaei, Preparation of martite nanoparticles through high-energy planetary ball milling and its application toward simultaneous catalytic ozonation of two green algae, J. Taiwan Inst. Chem. Eng. 82 (2018) 80-91. https://doi.org/10.1016/j.jtice.2017.10.016.

[28] M. Fathinia, A. Khataee, Photocatalytic ozonation of phenazopyridine using $\mathrm{TiO}_{2}$ nanoparticles coated on ceramic plates: mechanistic studies, degradation intermediates and ecotoxicological assessments, Appl. Catal. Gen. 491 (2015) 136-154. https://doi.org/10.1016/j.apcata.2014.10.049.

[29] A. P. LaGrow, M. O. Besenhard, A. Hodzic, A. Sergides, L. K. Bogart, A. Gavriilidis, N.T. Kim Thanh, Unravelling the growth mechanism of the co-precipitation of iron oxide nanoparticles with the aid of synchrotron X-Ray diffraction in solution, Nanoscale. 11 (2019) 6620-6628. https://doi.org/10.1039/C9NR00531E.

[30] H. Zhang, V. Malik, S. Mallapragada, M. Akinc, Synthesis and characterization of Gddoped magnetite nanoparticles, J. Magn. Magn. Mater. 423 (2017) 386-394. https://doi.org/10.1016/j.jmmm.2016.10.005.

[31] G.T. Sulungbudi, Y. Yuliani, W.Z. Lubis, S. Sugiarti, M. Mujamilah, controlled growth of iron oxide magnetic nanoparticles via co-precipitation method and $\mathrm{NaNO}_{3}$ addition, J. Sains Materi Indones. $18 \quad$ (2017) 136-143. https://doi.org/10.17146/jsmi.2017.18.3.4122. 
[32] S.M. Bird, J.M. Galloway, A.E. Rawlings, J.P. Bramble, S.S. Staniland, Taking a hard line with biotemplating: cobalt-doped magnetite magnetic nanoparticle arrays, Nanoscale. 7 (2015) 7340-7351. https://doi.org/10.1039/C5NR00651A.

[33] L.B. de Mello, L.C. Varanda, F.A. Sigoli, I.O. Mazali, Co-precipitation synthesis of (Zn-Mn)-co-doped magnetite nanoparticles and their application in magnetic hyperthermia, J. Alloys Compd. $779 \quad$ (2019) 698-705. https://doi.org/10.1016/j.jallcom.2018.11.280.

[34] J.M. Galloway, A. Arakaki, F. Masuda, T. Tanaka, T. Matsunaga, S.S. Staniland, Magnetic bacterial protein Mms6 controls morphology, crystallinity and magnetism of cobalt-doped magnetite nanoparticlesin vitro, J. Mater. Chem. 21 (2011) 15244-15254. https://doi.org/10.1039/C1JM12003D.

[35] Aashima, S. Uppal, A. Arora, S. Gautam, S. Singh, R. J. Choudhary, S. K. Mehta, Magnetically retrievable Ce-doped Fe 3 O 4 nanoparticles as scaffolds for the removal of azo dyes, RSC Adv. 9 (2019) 23129-23141. https://doi.org/10.1039/C9RA03252E.

[36] S. Rahim Pouran, A. Bayrami, A.A. Abdul Raman, W.M.A. Wan Daud, M.S. Shafeeyan, A. Khataee, Comprehensive study on the influence of molybdenum substitution on characteristics and catalytic performance of magnetite nanoparticles, Res. Chem. Intermed. 44 (2018) 883-900. https://doi.org/10.1007/s11164-017-3142-x.

[37] P. Yekan Motlagh, A. Khataee, T. Sadeghi Rad, A. Hassani, S.W. Joo, Fabrication of ZnFe-layered double hydroxides with graphene oxide for efficient visible light photocatalytic performance, J. Taiwan Inst. Chem. Eng. 101 (2019) 186-203. https://doi.org/10.1016/j.jtice.2019.04.051.

[38] R. Kaveh, H. Alijani, M.H. Beyki, Magnetic polyresorcinol@ $\mathrm{CoFe}_{2} \mathrm{O}_{4} @ \mathrm{MnS}$ nanoparticles for adsorption of $\mathrm{Pb}(\mathrm{II}), \mathrm{Ag}(\mathrm{I}), \mathrm{Cr}(\mathrm{VI})$ and bacteria from water solution, Polym. Bull. (2019). https://doi.org/10.1007/s00289-019-02835-7. 
[39] M. Kuang, T.T. Li, H. Chen, S.M. Zhang, L.L. Zhang, Y.X. Zhang, Hierarchical $\mathrm{Cu}_{2} \mathrm{O} / \mathrm{CuO} / \mathrm{Co}_{3} \mathrm{O}_{4}$ core-shell nanowires: synthesis and electrochemical properties, Nanotechnology. 26 (2015) 304002. https://doi.org/10.1088/0957-4484/26/30/304002.

[40] S. Yang, J.-T. Jiang, C.-Y. Xu, Y. Wang, Y.-Y. Xu, L. Cao, L. Zhen, Synthesis of Zn(II)-Doped Magnetite Leaf-Like Nanorings for Efficient Electromagnetic Wave Absorption, Sci. Rep. 7 (2017) 1-10. https://doi.org/10.1038/srep45480.

[41] C. Yang, W. Dong, G. Cui, Y. Zhao, X. Shi, X. Xia, B. Tang, W. Wang, Highlyefficient photocatalytic degradation of methylene blue by PoPD-modified $\mathrm{TiO}_{2}$ nanocomposites due to photosensitization-synergetic effect of $\mathrm{TiO}_{2}$ with PoPD, Sci. Rep. 7 (2017) 1-12. https://doi.org/10.1038/s41598-017-04398-X.

[42] C. Cai, J. Liu, Z. Zhang, Y. Zheng, H. Zhang, Visible light enhanced heterogeneous photo-degradation of Orange II by zinc ferrite $\left(\mathrm{ZnFe}_{2} \mathrm{O}_{4}\right)$ catalyst with the assistance of $\begin{array}{llllll}\text { persulfate, } & \text { Sep. } & \text { Purif. } & \text { Technol. } & 165 & \text { (2016) }\end{array}$ https://doi.org/10.1016/j.seppur.2016.03.026.

[43] Y. Liu, W. Guo, H. Guo, X. Ren, Q. $\mathrm{Xu}, \mathrm{Cu}$ (II)-doped $\mathrm{V}_{2} \mathrm{O}_{5}$ mediated persulfate activation for heterogeneous catalytic degradation of benzotriazole in aqueous solution, Sep. Purif. Technol. 230 (2020) 115848. https://doi.org/10.1016/j.seppur.2019.115848.

[44] K. Song, X. Zhou, Y. Liu, Y. Gong, B. Zhou, D. Wang, Q. Wang, Role of oxidants in enhancing dewaterability of anaerobically digested sludge through Fe (II) activated oxidation processes: hydrogen peroxide versus persulfate, Sci. Rep. 6 (2016) 1-9. https://doi.org/10.1038/srep24800.

[45] S. Rahim Pouran, A. Bayrami, A.R. Abdul Aziz, W.M.A. Wan Daud, M.S. Shafeeyan, Ultrasound and UV assisted Fenton treatment of recalcitrant wastewaters using transition metal-substituted-magnetite nanoparticles, J. Mol. Liq. 222 (2016) 10761084. https://doi.org/10.1016/j.molliq.2016.07.120. 
[46] P. Gholami, L. Dinpazhoh, A. Khataee, A. Hassani, A. Bhatnagar, Facile hydrothermal synthesis of novel $\mathrm{Fe}-\mathrm{Cu}$ layered double hydroxide/biochar nanocomposite with enhanced sonocatalytic activity for degradation of cefazolin sodium, J. Hazard. Mater. (2019) 120742. https://doi.org/10.1016/j.jhazmat.2019.120742.

[47] J. Zhao, Y. Zhang, X. Quan, S. Chen, Enhanced oxidation of 4-chlorophenol using sulfate radicals generated from zero-valent iron and peroxydisulfate at ambient $\begin{array}{llllll}\text { temperature, } & \text { Sep. } & \text { Purif. } & \text { Technol. } & 71 & \text { (2010) }\end{array}$ https://doi.org/10.1016/j.seppur.2009.12.010.

[48] D. Ouyang, J. Yan, L. Qian, Y. Chen, L. Han, A. Su, W. Zhang, H. Ni, M. Chen, Degradation of 1,4-dioxane by biochar supported nano magnetite particles activating $\begin{array}{lllll}\text { persulfate, } & \text { Chemosphere. } & 184 & \text { 609-617. }\end{array}$ https://doi.org/10.1016/j.chemosphere.2017.05.156.

[49] J. Wang, M. Shen, Q. Gong, X. Wang, J. Cai, S. Wang, Z. Chen, One-step preparation of ZVI-sludge derived biochar without external source of iron and its application on $\begin{array}{llllll}\text { persulfate } & \text { activation, } & \text { Sci. } & \text { Total Environ. } & 714 & \text { (2020) }\end{array}$ https://doi.org/10.1016/j.scitotenv.2020.136728.

[50] J.M. Monteagudo, H. El-taliawy, A. Durán, G. Caro, K. Bester, Sono-activated persulfate oxidation of diclofenac: Degradation, kinetics, pathway and contribution of the different radicals involved, J. Hazard. Mater. 357 (2018) 457-465. https://doi.org/10.1016/j.jhazmat.2018.06.031.

[51] C. Liang, Z.-S. Wang, C.J. Bruell, Influence of $\mathrm{pH}$ on persulfate oxidation of TCE at ambient temperatures, Chemosphere. $66 \quad$ (2007) 106-113. https://doi.org/10.1016/j.chemosphere.2006.05.026.

[52] M. Pu, Y. Ma, J. Wan, Y. Wang, M. Huang, Y. Chen, Fe/S doped granular activated carbon as a highly active heterogeneous persulfate catalyst toward the degradation of 
Orange G and diethyl phthalate, J. Colloid Interface Sci. 418 (2014) 330-337. https://doi.org/10.1016/j.jcis.2013.12.034.

[53] M. Kermani, F. Mohammadi, B. Kakavandi, A. Esrafili, Z. Rostamifasih, Simultaneous catalytic degradation of 2,4-D and MCPA herbicides using sulfate radical-based heterogeneous oxidation over persulfate activated by natural hematite ( $\alpha$-Fe2O3/PS), J. Phys. Chem. Solids. 117 (2018) 49-59. https://doi.org/10.1016/j.jpcs.2018.02.009.

[54] M. Kumar, A. Puri, A review of permissible limits of drinking water, Indian J. Occup. Environ. Med. 16 (2012) 40-44. https://doi.org/10.4103/0019-5278.99696.

[55] R. Saffari, Z. Shariatinia, M. Jourshabani, Synthesis and photocatalytic degradation activities of phosphorus containing $\mathrm{ZnO}$ microparticles under visible light irradiation for water treatment applications, Environ. Pollut. $259 \quad$ (2020) 113902. https://doi.org/10.1016/j.envpol.2019.113902.

[56] B. Jung, W. Deng, Y. Li, B. Batchelor, A. Abdel-Wahab, Simulated solar light-driven photocatalytic degradation of trichloroethylene in water using $\mathrm{BiOBr}$ promoted by sulfite addition, Environ. Sci. Eur. 32 (2020) 8. https://doi.org/10.1186/s12302-0190287-9.

[57] H. Milh, B. Schoenaers, A. Stesmans, D. Cabooter, R. Dewil, Degradation of sulfamethoxazole by heat-activated persulfate oxidation: Elucidation of the degradation mechanism and influence of process parameters, Chem. Eng. J. 379 (2020) 122234. https://doi.org/10.1016/j.cej.2019.122234.

[58] H. Hu, H. Zhang, Y. Chen, Y. Chen, L. Zhuang, H. Ou, Enhanced photocatalysis degradation of organophosphorus flame retardant using MIL-101(Fe)/persulfate: Effect of irradiation wavelength and real water matrixes, Chem. Eng. J. 368 (2019) 273-284. https://doi.org/10.1016/j.cej.2019.02.190. 
[59] D. Fabbri, M.J. López-Muñoz, A. Daniele, C. Medana, P. Calza, Photocatalytic abatement of emerging pollutants in pure water and wastewater effluent by $\mathrm{TiO}_{2}$ and $\mathrm{Ce}-\mathrm{ZnO}$ : degradation kinetics and assessment of transformation products, Photochem. Photobiol. Sci. 18 (2019) 845-852. https://doi.org/10.1039/C8PP00311D.

[60] O. Monfort, G. Voyard, M. Brigante, G. Mailhot, Innovative depollution treatment using multi-valent iron species: from fundamental study to application in municipal wastewater, Environ. Sci. Pollut. Res. $27 \quad$ (2020) 19736-19745. https://doi.org/10.1007/s11356-020-08502-z.

[61] W. Huang, A. Bianco, M. Brigante, G. Mailhot, UVA-UVB activation of hydrogen peroxide and persulfate for advanced oxidation processes: Efficiency, mechanism and effect of various water constituents, J. Hazard. Mater. 347 (2018) 279-287. https://doi.org/10.1016/j.jhazmat.2018.01.006. 